\title{
„Było błędem nie uwzględniać psychologii serca młodzieńczego wojownika..." Arcybiskupa Józefa Teofila Teodorowicza krytyka NKN i Legionów
}

\begin{abstract}
Abstrakt: W tekście przedstawione zostały poglądy polityczne jednego z czołowych działaczy politycznych początku XX w. - ostatniego arcybiskupa ormiańskokatolickiego - Józefa Teofila Teodorowicza. Przeanalizowano jego stosunek do rozwijającego się na ziemiach polskich ruchu irredentystycznego, a następnie jego wybór opcji politycznej w momencie wybuchu Wielkiej Wojny i stosunek do Naczelnego Komitetu Narodowego. Przedstawione zostały poglądy abp. Teodorowicza wobec najważniejszych wydarzeń rozgrywających się na ziemiach polskich do końca 1917 r.
\end{abstract}

Słow a klu c z ow e: abp Józef T. Teodorowicz, I wojna światowa, Naczelny Komitet Narodowy $(\mathrm{NKN})$, Legiony Polskie, myśl polityczna.

Abstract: The text presents political opinions of one of the leading politicians of the early twentieth century - the last Armenian Catholic archbishop - Józef Teofil Teodorowicz. His attitude towards the irredentist movement developing in the Polish lands is analysed, and then his choice of a political option at the outbreak of the Great War together with his attitude towards the Supreme National Council (SNC). Archbishop Teodorowicz's views on the most important events occurring in the Polish lands up to the end of 1917 are presented.

Keywords: Archbishop Josef Teodorowicz, World War I, Supreme National Committee, Polish Legions, political thought.

Józef Teofil Teodorowicz - ostatni arcybiskup ormiańskokatolicki zasłynał nie tylko jako jeden z najwybitniejszych biskupów katolickich na ziemiach polskich w pierwszej połowie XX w., ale również jeden z wielkich mężów stanu 
swojej epoki. Był znakomitym politykiem i dyplomata, gorliwym i czujnym patriota, nazywanym przez wielu mózgiem i sumieniem episkopatu polskiego. Związany z ugrupowaniami politycznymi wyrosłymi z Narodowej Demokracji, należał do szeroko rozumianej opcji chadeckiej, do której część badaczy zalicza Narodowo-Chrześcijańskie Stronnictwo Ludowe¹. Pozostał w pamięci jako prawdziwy patriota, niestrudzenie broniący polskich praw narodowych i interesów. Stanisław Stroński przyrównał go do dzwonu Zygmunta, który „przemawia” do narodu w najważniejszych chwilach ${ }^{2}$.

Arcybiskup Teodorowicz należał do duchownych, którzy żywili przekonanie, że bezpośrednia aktywność polityczna ma znacznie większe możliwości wpływania w duchu katolickim na państwo niż tylko praca formacyjna. W przededniu wybuchu I wojny światowej abp Teodorowicz był członkiem Ligi Polskiej i współpracował z ugrupowaniem „Rzeczypospolita”, zwłaszcza z Edwardem Dubanowiczem i Stanisławem Strońskim, a także z konserwatystami wschodniogalicyjskimi (podolakami) - Dawidem Abrahamowiczem i Aleksandrem Krzeczunowiczem ${ }^{4}$. W Sejmie Krajowym wspomagał od 1912 r. konserwatywno-narodowy Klub Środka, stale współpracujący z endecją Teodorowicz znany już ze swojej działalności politycznej we wszystkich trzech zaborach, odegrał również znacząca rolę w wyborach, jakie dokonywało społeczeństwo polskie w trudnych latach I wojny światowej. Tekst ten skupia się jedynie na jego aktywności politycznej w okresie działania Naczelnego Komitetu Narodowego (NKN), pomijając zaangażowanie arcybiskupa w działalność społeczną i charytatywna. Moim celem było znalezienie odpowiedzi na pytania: czy słusznie uważano Teodorowicza za szarą eminencję endecji, czy może był wybitnym graczem politycznym, którego cechował przede wszystkim zdrowy rozsądek? Jak rozumiał pojęcie „dobra narodu”, jako duchowny, polityk, członek społeczeństwa oczekującego wskrzeszenia

${ }^{1}$ Zob. W. Jakubowski, Chrześcijańska Demokracja, w: Polskie partie i ruchy społeczno-polityczne pierwszej połowy XX wieku, red. nauk. K. Przybysz, Warszawa 2010, s. 204.

${ }^{2}$ R. Król-Mazur, Działalność polityczna arcybiskupa Józefa Teofila Teodorowicza w latach 1888-1923, Kraków 2013, s. 146.

${ }^{3}$ Założone w styczniu 1909 r. przez secesjonistów ze Stronnictwa Demokratyczno-Narodowego, korzystało z politycznego i materialnego wsparcia konserwatystów wschodniogalicyjskich.

${ }^{4}$ Dwaj ostatni byli Polakami pochodzenia ormiańskiego. Stan stosunków narodowościowych w Galicji, jaki zaczął się wytwarzać pod koniec XIX w., uzmysłowił polskim Ormianom, że ich sukces w postaci wejścia do różnych polskich warstw społecznych nie jest stabilny. Pozycję całej społeczności polskiej coraz silniej podkopywały roszczenia Ukraińców i Żydów, którzy nie asymilowali się i sformowali dwa odrębne wobec polskiego programy narodowe. Dlatego też polscy Ormianie w Galicji Wschodniej stali się zapleczem dla coraz bardziej popularnej ideologii nacjonalistycznej i SDN. K. Stopka, Ormianie w Galicji Austriackiej, w: Ormiański pasterz Lwowa ksiadz arcybiskup Józef Teodorowicz na tle dziejów ormiańskich, red. W. Osadczy, ks. M. Kalinowski, M. Jacov, Lublin-Lwów 2015, s. 109.

${ }^{5}$ A. Wątor, Działalność Stronnictwa Demokratyczno-Narodowego w zaborze austriackim do roku 1914, Szczecin 1993, s. 31-32. 
państwa polskiego? Co sprawiało, że obojętnie jakie żywiono wobec niego uczucia, wszyscy zabiegali o jego przychylność? Analiza ewolucji zapatrywań politycznych abp. Teodorowicza oparta została w głównej mierze na źródłach, których twórca był on sam bądź pochodziły od grona osób, z którymi blisko współpracował.

Dla Polaków mieszkających w zaborze austriackim wybór orientacji politycznej sprawiał niezwykła trudność. Przywiązanie do monarchii, swobody polityczne, faktyczne sprawowanie przez Polaków kierownictwa w kraju budziły sympatie do Austro-Węgier, przysłaniając nawet fakt zależności od niemieckiego sojusznika. Współpraca z Rosja, wobec nasilenia akcji rusyfikacyjnej i dążenia do opanowania w przyszłej wojnie Galicji, była dla Polaków mieszkających w Galicji nie do przyjęcia. Dla wszystkich ugrupowań galicyjskich kwestia wyboru orientacji od 1912 r. stała się jednym z głównych problemów. Działacze narodowi, którzy niejednokrotnie obradowali u abp. Józefa Teodorowicza, przyjęli stanowisko, że bezwzględne związanie sprawy polskiej z Austrią w razie wojny byłoby bardzo ryzykowne ${ }^{6}$. Główny cel stanowiło niepodległe państwo polskie, obejmujące wszystkie dzielnice zajęte przez zaborców. W celu zaangażowania opinii światowej w problemy polskie środowiska narodowe powołały dwa biura prasowe (w 1911 r. w Rzymie oraz w 1913 r. w Londynie), prowadzące akcję informacyjno-propagandowa, której intensyfikacja nastapiła wraz z wybuchem wojny. Teodorowicz nie tylko udzielił im poparcia, ale również przekazał pisma dla tamtejszych ministerstw spraw zagranicznych, jak i instrukcje polityczne dla działaczy tych biur? ${ }^{7}$.

Działalność irredenty polskiej w przededniu I wojny światowej abp Teodorowicz obserwował z zaniepokojeniem, przestrzegajac (m.in. w słynnej homilii wygłoszonej w lwowskiej archikatedrze z okazji 50. rocznicy powstania styczniowego), że „nie można i nie wolno jest iść za porywami, choćby najszczytniejszymi, bez przemyślenia i przygotowania, z dziecięcą niemal lekkomyślnością. Nie wolno jest takiego porywu za wzór przyszłości narodu stawiać". Teodorowicz już wtedy dał wyraz swojemu bardzo krytycznemu osądowi na temat postępowania Europy wobec Polaków, co później z cała surowością powtórzył w 1917 r. w swoich słynnych wystapieniach w Radzie Państwa. Jego słowa miały ostudzić przedwojenną gorączkę działaczy irredentystycznych oraz wpłynąć na polityków:

\footnotetext{
${ }_{6}^{6}$ J. Faryś, A. Wątor, Edward Dubanowicz 1881-1943. Biografia polityczna, Szczecin 1994, s. 35; A. Wątor, Galicyjska Rada Narodowa w latach 1907-1914. Z dziejów instytucji obywatelskiej, Szczecin 2000, s. 181, przypis 16.

${ }^{7}$ R. Król-Mazur, Działalność polityczna..., s. 68.

${ }^{8}$ J. Teodorowicz, Dwie epoki. Mowa wypowiedziana w r. 1913 w archikatedrze lwowskiej w 50-ta rocznice powstania 63 r., w: idem, Kazania o Bogu i Ojczyźnie, Warszawa 1999, s. 18.
} 
Duch dyplomacji jest wobec Polski zawsze ten sam i w niczym się nie odmienił. Pozbawiona wszelkiego zmysłu dla wyrozumienia niesprawiedliwości dziejowej, zimna dla nas i nieczuła, gotowa jest jednak zawsze lekkomyślnie i dla własnej tylko korzyści, obietnicami dla nas szafować. Na tym jednym tylko jej zależy, ażeby nas nakłonić do ofiar, które są dla niej chwilowo korzystne albo potrzebne. Lecz jakże nieskoro jest jej potem poczynionych obietnic dotrzymywać, a nawet nie poczuje się do żadnej odpowiedzialności za udzielone przez siebie rady albo obudzone nadzieje. Każdej chwili umyje ona po piłatowsku ręce od naszej sprawy, skoro naiwni i oszukani przypomnimy jej zobowiązania ${ }^{9}$.

Kiedy wybuchła Wielka Wojna abp Teodorowicz jeszcze dobitniej wyraził swoje zdanie na temat zachowania mocarstw europejskich, przyrównując ich do biblijnych faryzeuszy: „Wsłuchuję się jak w ciagu tych kilku lat państwa i narody odwołują się do sprawiedliwości i prawdy i jak ongi[ś] szkoły faryzejskie, tak dziś prześcigaja się one wzajem w tym, kto da więcej. Jak ongi faryzeizm umywał ręce, tak oni dziś umywają ręce po faryzejsku, by jeden na drugiego zwalać winę za krew"10.

Ponieważ od 1908 r. rozwój sytuacji nakazywał podjęcie konkretnych działań, abp Teodorowicz wsparł swoim autorytetem Drużyny Bartoszowe ${ }^{11}$ i Polowe Drużyny Sokole ${ }^{12}$ - organizacje konkurencyjne z tworzonymi przez lewicę niepodległościową Związkami Strzeleckimi i „Strzelcem”13.

I wojna światowa dla abp. Teodorowicza nie była wojna Polaków. Hołdował lojalności wobec dynastii, jednocześnie głosząc prawa Polaków do niepodległości. Od początku sprzeciwiał się doktrynie trójlojalizmu i panslawizmu. Uważał, że państwowość polską można odbudować albo przez oddanie Polakom prawa do zorganizowania państwa, albo przez współdziałanie innych państw. Podobnie jak „Rzeczypospolita”, był za tzw. orientacją polską - wykorzystać swobody austriackie, stworzyć wojsko narodowe, atakować Rosję, ale przede wszystkim uzyskać od państw centralnych gwarancję powołania państwa polskiego z ziem zaboru rosyjskiego i austriackiego ${ }^{14}$. Krytykował służalczość

9 Ibidem, s. 28.

${ }^{10}$ Kazanie abp J. Teodorowicza, bm i bd., Centralne Państwowe Archiwum Historyczne miasta Lwowa (dalej: CDIAUL), Fond 475, sprawa (spr.) 60, k. 118.

${ }^{11}$ Utworzone w 1908 r. we Lwowie z inicjatywy Wawrzyńca Dajczaka przez młodzież z grupy „Rzeczypospolita”. Początkowo były organizacją przysposobienia wojskowego, a od $1912 \mathrm{r}$. funkcjonowały jako organizacja wojskowa. Na przełomie lipca i sierpnia 1914 r. połączyły się z Polowymi Drużynami Sokolimi pod egidą Centralnego Komitetu Narodowego i weszły w skład Legionu Wschodniego.

12 Te ochotnicze paramilitarne formacje „Sokoła” zostały założone z inicjatywy galicyjskiego Stronnictwa Demokratyczno-Narodowego i lwowskiej Ligii Narodowej w 1912 r.

13 A. Wątor, Chrześcijańsko-narodowi. Z dziejów nurtu politycznego do 1928 roku, Szczecin 1999, s. 71.

${ }_{14}$ T.M. Trajdos, Uwagi o działalności politycznej i przekonaniach arcybiskupa Józefa Teodorowicza, w: Teodorowicz. Mówca i patriota, red. T. Skoczek, Warszawa 2015, s. 85. 
wobec rządów zaborczych. Dwór cesarski znając jego poglądy, ograniczał jego działalność publiczna do minimum ${ }^{15}$.

Decyzję o powołaniu w Krakowie 16 VIII 1914 r. NKN ${ }^{16}$, w którym pierwsze skrzypce grali konserwatyści krakowscy, a który miał być platforma współpracy najważniejszych stronnictw politycznych Galicji, abp Teodorowicz przyją ze sceptycyzmem ${ }^{17}$. NKN był politycznym i logistycznym zapleczem Legionów Polskich walczących w czasie I wojny światowej w ramach armii austro-węgierskiej. Dążył do ścisłego związania kwestii niepodległości Polski z monarchia habsburska ${ }^{18}$. Część polityków galicyjskich zmierzała do zjednoczenia Galicji z wyzwolonym spod panowania rosyjskiego Królestwem Polskim i utworzenia trzeciego członu monarchii habsburskiej. Opowiadając się za tą opcja, NKN musiał w momencie wybuchu wojny uznać Niemcy za swojego sojusznika. Społeczeństwo polskie jednak nie wierzyło w dobrą wolę tego sojusznika. O złej sławie Niemiec decydowały wcześniejsza antypolska polityka prowadzona przez rząd berliński oraz propaganda Narodowej Demokracji (ND) podkreślająca zagrożenie odwiecznym germańskim ekspansjonizmem ${ }^{19}$. Negatywne nastawienie do Niemiec ugruntowało zachowanie w czasie działań wojennych, kiedy ich wojska dopuszczały się okrucieństw i grabieży. Tymczasem w Berlinie już w momencie wybuchu wojny narodził się plan oderwania Królestwa Polskiego od Rosji i stworzenia czegoś na kształt Księstwa Warszawskiego - państwa, które stanowiłoby satelitę Niemiec i zarazem bufor oddzielający je od wschodniego sąsiada ${ }^{20}$. Tych planów nie można było pogodzić z koncepcja austro-polska. „Dziennik Polski” z 12 XII 1914 r. w artykule Rola Polaków w Wiedniu domagał się od polityków majacych wpływy w najważniejszych kołach wiedeńskich, aby „w imię interesu narodowego parli Austrię do zerwania z Prusami”, bowiem „Polacy nie maja gorszego i bardziej nieprzejednanego wroga niż Prusy"21.

${ }^{15}$ A. Kudłaszyk, Elementy doktryny społeczno-politycznej abp. Józefa Teodorowicza, „Roczniki Teologiczno-Kanoniczne” 1980, t. XXVII, z. 4, s. 38-39.

${ }^{16}$ Dzielił się na sekcję zachodnią (krakowska) pod przewodnictwem Władysława Leopolda Jaworskiego oraz wschodnią (lwowska), na której czele stał Tadeusz Cieński. Departamentem Wojskowym NKN kierował płk Władysław Sikorski.

${ }_{17}$ Były w nim początkowo reprezentowane wszystkie partie Galicji i proaustriackie stronnictwa z Królestwa Polskiego. Wkrótce jednak z organizacji wystapili galicyjscy narodowi demokraci i podolacy.

${ }^{18}$ Szerzej na ten temat zob. W. Suleja, Orientacja austro-polska $w$ latach I wojny światowej (do aktu 5 listopada 1916 roku), Wrocław 1992.

19 Szerzej na ten temat zob. M.M. Drozdowski, Dylematy polityki Naczelnego Komitetu Narodowego wobec Niemiec (do aktu 5 listopada 1916 r.), „Studia Historyczne” R. LV, 2012, z. 1 (217), s. 27-49.

${ }^{20}$ D. Szymczak, Niemiecko-austro-wegierski spór o przyszłość Polski a narodziny państwowości polskiej w 1918 roku, w: Rok 1918 w Europie Środkowo-Wschodniej, red. D. Grinberg, J. Snopko, G. Zackiewicz, Białystok 2010, s. 117.

${ }^{21}$ Zob. Archiwum Narodowe w Krakowie (dalej: ANK), Archiwum Naczelnego Komitetu Narodowego (dalej: ANKN), sygn. 80, Mikrofilm (MF) 100, 270, s. 34. 
Prace NKN utrudniał również fakt, że powstał on na podstawie kruchego kompromisu zawartego między partiami o kierunku proaustriackim a stronnictwami prawicowymi ciążącymi ku niechętnej Habsburgom ND ${ }^{22}$.

Polska społeczność Lwowa entuzjastycznie przyjęła informację o powołaniu NKN, o czym przekonujemy się, czytając „Kurier Lwowski” ${ }^{23}$. Wobec powszechnej euforii panującej $\mathrm{w}$ tym mieście trudno było tamtejszym politykom nawoływać do rozsądku i wstrzemięźliwości. Zupełnie odmienne nastroje panowały w Królestwie Polskim - wielu polityków warszawskich, zwłaszcza konserwatystów, nie mogło uwierzyć, że w Krakowie powstała reprezentacja narodowa, w której razem z socjalistami, na czele z Ignacym Daszyńskim, zasiadaja przedstawiciele konserwatystów i arystokracji, jak Zdzisław hr. Tarnowski czy Witold ks. Czartoryski² ${ }^{4}$.

Arcybiskup Józef Teodorowicz był przeciwnikiem linii politycznej przyjętej przez konserwatystów krakowskich i NKN, który uważał za powołany wyłącznie do realizacji partyjnych celów socjalistów i konserwatystów krakowskich. Niejednokrotnie oświadczał, że nie zaakceptuje NKN ze względu na udział w nim Żydów i socjalistów (w połowie $1916 \mathrm{r}$. arcybiskup zaliczał do socjalistów również Władysława Sikorskiego, jedną z czołowych postaci Polskiego Stronnictwa Postępowego) i ich silne wpływy ${ }^{25}$. Był to pogląd charakterystyczny dla ludzi związanych z ND i podolakami. Dla nich „Przewodnią role w N.K.N. objęły jednostki z partii krakowskiej w połączeniu z socjalistami. Żywioły te, pozornie sprzeczne i skrajne, doskonale się rozumiały i uzupełniały, bo je łączyła wspólna nienawiść do "endeków»" ${ }^{26}$. To nieprawdziwe przekonanie o dominacji socjalistów w NKN potrafiło jednak odsuwać od udzielenia mu poparcia zachowawczą część społeczeństwa. Ubolewał nad tym prezes NKN Władysław Leopold Jaworski, zapewniając, że tych czterech socjalistów, którzy są w NKN, nie może wywierać na niego żadnego wpływu. Obwiniał za to endecję i podolaków, którzy według niego nie dotrzymali słowa, rozpuścili Legion Wschodni, wystapili z NKN i zaczęli szerzyć opinię, że NKN jest w rękach socjalistów i nazywa się rządem narodowym ${ }^{27}$. Teodorowiczowi jednak chodziło nie o liczbę socjalistów w Komitecie, ale socjalistycznego ducha NKN, jego kierunek działania, metody i zasady. Według arcybiskupa cała organizacja

${ }^{22}$ Szerzej zob. R. Król-Mazur, Idea odrodzonego państwa polskiego w pogladach galicyjskich ugrupowań politycznych do utworzenia Naczelnego Komitetu Narodowego, „Politeja” 2010, nr 2, s. 269-300.

${ }^{23}$ J.Z. Pająk, Lwów podczas pierwszych dni Wielkiej Wojny 1914-1918, w: Znani i nieznani międzywojennego Lwowa. Studia i materiaty, t. III, red. M. i M. Przeniosło, Kielce 2012, s. 112.

24 J. Molenda, Pitsudczycy a narodowi demokraci 1908-1918, Warszawa 1980, s. 190.

25 J. Hupka, Z czasów wielkiej wojny. Pamiętniki nie kombatanta, Lwów 1937, s. 204-206, 266; J. Teodorowicz, Stańczyk bez Teki. Odpowiedź na „Dialog o zasadach i kompromisach”, Lwów 1916 [drukowane jako manuskrypt - dlatego praca ta jest unikatem], s. 61.

${ }_{26}$ S. Głąbiński, Wspomnienia polityczne, t. I, Pelpin 1939, s. 209.

27 ANK, Archiwum Dzikowskie Tarnowskich (dalej: ADzT), sygn. 1127, W.L. Jaworski do Z.A. Tarnowskiego, Kraków 30 VI 1915, s. 349-350, 361. 
NKN, jego propaganda i aparat prasowy zostały opanowane przez ducha socjalistycznego ${ }^{28}$. Nie zgadzał się też z opcja polityczną wybraną przez NKN. Nie dzielił zaborców na „złych”, „dobrych” i „lepszych”, dlatego też w jego wypowiedziach pojawiały się akcenty piętnujące podłość Niemiec, matactwa Austrii, brutalność Rosji. Był przeciwny wiązaniu się jakimikolwiek więzami z Niemcami. Według niego historia pokazała nam, czego mogliśmy doznać od Niemców, a doświadczenia Wielkiej Wojny (aneksje, rabunki, niszczenie gospodarki) stanowiły tego najlepszy dowód ${ }^{29}$. Dla abp. Teodorowicza Niemcy były wrogiem Polski „więcej przemyślnym i wyrachowanym niż Rosja” ${ }^{30}$.

Straszenie socjalistami na tyle skutecznie działało na część społeczeństwa polskiego, że sam NKN posługiwał się tą metodą w zwalczaniu działalności POW, przedstawiając ją ,jako robotę socjalistyczną" ${ }^{11}$.

Arcybiskup Teodorowicz uważał, że nienawiść do ugrupowań zachowawczych najlepiej wyraził NKN na łamach wydawanego przez siebie organu prasowego „Wiadomości Polskie”, w wierszu Konstantego Srokowskiego (sekretarza generalnego NKN, partyjnie związanego z PSD), pt. Hymn do dnia dzisiejszego, w którym padły bardzo ostre słowa:

Więc nienawidzę was,

co stajecie na czele,

ognia gasiciele,

ducha zabójcy,

zapory na wyzwoleń drodze

W kontuszu, czy w todze,

czy też w biskupiej chodzący infule... ${ }^{32}$

Znamienne jest to, iż wiersz ukazał się 23 IV 1916 r. - można powiedzieć „w przeddzień" mającego się dokonać zjednoczenia w NKN. Zamiast nawoływać do zgody, organ NKN straszył piętnem Targowicy każdego, kto byłby temu zjednoczeniu przeciwny.

Nie do zaakceptowania był dla niego również ton prasy NKN i różne występy mające cechy denuncjacji ${ }^{33}$. Krytykował cenzurę wprowadzoną przez Komitet, który wskazywał, jakie utwory - w tym również literackie - mogą być dopuszczone do użytku ${ }^{34}$. Teodorowicz niejednokrotnie w swoich wystapieniach

28 J. Teodorowicz, Stańczyk bez Teki..., s. 61-62.

${ }_{29}$ T.M. Trajdos, op. cit., s. 86.

${ }^{30}$ J. Teodorowicz, Dwie epoki..., s. 27.

${ }^{31}$ ANK, ANKN 105, MF 100, 295, Kopia Raportu dla Komendy Naczelnej Polskiej Organizacji Wojskowej w sprawie zwalczania Polskiej Organizacji Wojskowej przez Departament Wojskowy NKN (tzw. Krajowy Inspektorat Zaciagu), Warszawa 26 III 1917, s. 646.

32 J. Teodorowicz, Stańczyk bez Teki..., s. 66.

33 J. Hupka, op. cit., s. 204-206.

${ }^{34} \mathrm{Na}$ liście utworów zakazanych przez NKN znalazła się m.in. Rota Marii Konopnickiej. Zob. Biblioteka książąt Czartoryskich (dalej: B.Czart.), rkps 11826, Sprawozdanie z książek i broszur przeznaczonych dla Królestwa Polskiego 8 III 1915. 
oraz publikacjach polemizował z poglądami przedstawianymi w organach prasowych NKN - czego najlepszy wyraz dał w opublikowanej w 1916 r. pracy Stańczyk bez Teki. Odpowiedź na „Dialog o Zasadach i Kompromisach”.

Arcybiskup wielokrotnie skarżył się na nagonkę, jaką prasa związana z NKN uczyniła, wypisując na jego temat bałamutne doniesienia. Do takich zaliczył publikowane przez gazety na wiosnę $1916 \mathrm{r}$. informacje o projekcie sprowadzenia do Galicji 20 tys. Ormian zagrożonych po ludobójstwie z 1915 r. dalszym wyniszczeniem w imperium osmańskim. Mieli oni stanowić dywersję demograficzna przeciw zagrażajacym Polakom Ukraińcom. Co gorsza, mogliby oni przyczynić się do rearmenizacji Polaków pochodzenia ormiańskiego, co $\mathrm{w}$ konsekwencji wpłynęłoby na umniejszenie polskiego stanu posiadania na kresach południowo-wschodnich. W gazetach kładziono nacisk, że będzie to 20 tys. ludzi wrogich Turcji, a życzliwych Rosji, a tym samym niebezpiecznych dla państw centralnych ${ }^{35}$. Te doniesienia zostały w późniejszym czasie niesłusznie przyjęte przez historyków jako dowód na to, że abp Teodorowicz ponoć miał plan przyjścia w ten sposób z pomoca Ormianom tureckim ${ }^{36}$. Prasa jednak w tym okresie obfitowała w różnego rodzaju sensacyjne doniesienia - czego przykładem również mogą być informacje o projekcie „sprowadzenia 300000 kolonistów z Syberii dla zruszczenia Galicji” ${ }^{37}$.

Teodorowicz żalił się również, że działacze wschodniogalicyjscy, którzy w pierwszych miesiącach pracy NKN uczestniczyli w obradach sekcji zachodniej, obawiali się występować na zebraniach z własnymi poglądami, aby nie zostać zadenuncjowani ${ }^{38}$. Działacze zwiąani z obozem narodowodemokratycznym doświadczyli inwigilacji, nadzoru policyjnego, a nawet aresztu szczególnie nasiliło się to po rozpadzie NKN w październiku 1914 r. ${ }^{39}$ Sam abp Teodorowicz był bacznie obserwowany zarówno przez wojskowy wywiad

${ }_{35}$ Arcybiskup pisał, że „daremne były prostowania równie naiwnych, jak tendencyjnych pomysłów”. Archiwum Polskich Ormian (dalej: APO), Zbiory arcybiskupa Józefa Teodorowicza (dalej: Teodorowicz), teczka (t.) 117, sygn. 428/217[6], Pisma polityczne dotyczące NKN, k. 59 .

${ }^{36}$ Jako pierwszy przyją to Krzysztof Stopka. Zob. idem, Ormianie polscy w Galicji w czasach arcybiskupa Teodorowicza. Dyskusja na temat tożsamości, w: III Dni Kultury Ormiańskiej $w$ Gliwicach. Materiały informacyjne, Gliwice 2008, s. 24. Powtórzył to za nim Andrzej A. Zięba, szeroko rozpisując się na temat tego planu Teodorowicza przyjścia z pomocą rodakom zagrożonym utratą życia. Zob. A.A. Zięba, Czy można być ormiańskim patriota i polskim biskupem jednocześnie? Arcybiskup Józef Teodorowicz jako Ormianin, w: Ormiański pasterz Lwowa..., s. 222-224.

${ }^{37}$ Informowano przy tym, że nawet te działanie nie są w stanie zmienić prorosyjskiego nastawienia działaczy ND we Lwowie. Zob. B.Czart., rkps 11822, t. I, Sprawozdanie Sekretariatu Generalnego NKN (najprawdopodobniej marzec 1915 r.), k. 7. Jest to oczywiście niezgodne z prawda, bowiem endecy w Galicji nie mogli identyfikować się w całości z programem głoszonym przez Romana Dmowskiego. Zob. R. Król-Mazur, Idea odrodzonego państwa..., s. 293-297.

${ }^{38}$ Eadem, Działalność polityczna..., s. 73.

${ }^{39}$ Szerzej zob. J. Molenda, op. cit., s. 124-126. 
austriacki, jak i przez NKN - o czym świadczą chociażby szczegółowe informacje na jego temat w składanych raportach politycznych ${ }^{40}$.

Arcybiskup Teodorowicz bardzo surowo ocenił słynne posiedzenie NKN 20 X 1914 r., którego finał stanowiło rozbicie NKN i wystapienie z niego podolaków i endeków galicyjskich. Uważał, że były one dowodem szkodliwości sojuszu konserwatywno-socjalistycznego. Stawianie pod pręgierzem przywódców sekcji wschodniej NKN w momencie, kiedy sprawą rozwiązania Legionu Wschodniego zajęły się władze wojskowe i nic nie zostało jeszcze zbadane, świadczyło według niego o ukrytym planie, do którego konsekwentnie dążyli konserwatyści krakowscy i socjaliści. Teodorowicz głównego wroga, zmierzającego do zniszczenia sekcji wschodniej, upatrywał w osobie Władysława Leopolda Jaworskiego, prezesa sekcji zachodniej $\mathrm{NKN}^{41}$. Z postawionych na owym sławnym posiedzeniu NKN 20 X 1914 r. dwóch wniosków - jednego przez Ignacego Daszyńskiego (PPS), domagającego się uchwalenia wotum nieufności dla całej sekcji wschodniej - oraz drugiego przez Jana Dąbskiego (PSL) o wyrażenie ubolewania po zaistniałej sytuacji - konserwatyści krakowscy wybrali wniosek socjalistów, świadomie realizując zadanie pozbycia się $\mathrm{z}$ organizacji partii zachowawczych ${ }^{42}$.

Doprowadzenie do rozwiązania Legionu Wschodniego, który miał walczyć po stronie Austrii przeciwko Rosji, a następnie wycofanie się polityków narodowych z prac NKN zostały przedstawione przez zwolenników orientacji na państwa centralne jako deklaracja po stronie orientacji rosyjskiej. Polityków narodowych jako zdrajców „obrzucono błotem”. Według abp. Teodorowicza „sąd” nad sekcją wschodnią NKN był zemstą konserwatystów krakowskich za upadek w 1913 r. namiestnika Michała Bobrzyńskiego ${ }^{43}$, za który to obwiniali episkopat, podolaków i endecję ${ }^{44}$. Zalecał też zwracanie bacznej uwagi na rolę Bobrzyńskiego w Komitecie, „którego kariera związana jest najdelikatniejszymi nićmi z NKN"45. O dużym zaangażowaniu Bobrzyńskiego w popieraniu posunięć NKN mówił sam Jaworski ${ }^{46}$.

Arcybiskup Teodorowicz omawiając w Stańczyku bez Teki działania NKN w pierwszych miesiącach swej działalności, podkreślał, że konserwatyści krakowscy naginali prawo do swoich potrzeb, czego najlepszym przykładem

${ }^{40}$ CDIAUL, Fond 698, opis 1, spr. 1, Raport polityczny nr 12, Warszawa 14 III 1917, k. 70-71.

41 Jego osąd w tej sprawie nie był do końca prawdziwy, bowiem Jaworski na wcześniejszych sesjach sekcji zachodniej, np. 13 X 1914 r., nie wyraził zgody na poddanie pod dyskusję i głosowanie na postawione przez niektórych jej działaczy politycznych wnioski wyrażające osąd o postępowaniu sekcji wschodniej, bez wcześniejszego ustosunkowania się przez zainteresowanych do stawianych im zarzutów. Zob. B.Czart., rkps 11826, Dziennik Obwieszczeń Naczelnego Komitetu Narodowego - Sekcja Zachodnia, R. I, nr 4, 16 X 1914.

42 J. Teodorowicz, Stańczyk bez Teki..., s. 72-73.

${ }^{43}$ Szerzej na ten temat zob. R. Król-Mazur, Działalność polityczna..., s. 56-65.

44 J. Teodorowicz, Stańczyk bez Teki..., s. 81.

${ }^{45}$ Ibidem, s. 82.

${ }^{46}$ ANK, ADzT, sygn. 1127, W.L. Jaworski do Z.A. Tarnowskiego, Kraków 30 VI 1915, s. 351. 
były posiedzenia NKN z 17 i 18 IX 1914 r., kiedy rozpatrywano sprawę nadużyć popełnionych w Królestwie Polskim. Przedstawiciele sekcji wschodniej przeciwstawiali się wówczas powstawaniu Komisariatów Wojska Polskiego i werbunkowi do Legionów. Stroński przedstawił wniosek, w którym była mowa - zgodnie z zasadą ustalona przy powołaniu NKN - że „stanowienie o politycznych sprawach Królestwa może nastapić tylko za porozumieniem z organizacja w Królestwie Polskim, zbudowaną na podobnych zasadach, co wspólna organizacja w Galicji” ${ }^{47}$. Ponieważ socjaliści zagrozili, że w przypadku jego przyjęcia wystapią z NKN, główni działacze komitetu - Władysław L. Jaworski i Juliusz Leo - zawiesili obrady, uniemożliwiając głosowanie nad wnioskiem Strońskiego. Teodorowicz zwrócił tu uwagę na - stosowana również później przez Jaworskiego - taktykę odraczania obrad, aby nie dopuścić do głosowania nad sprawami niewygodnymi dla opcji politycznej przywódców NKN. Kiedy w kwietniu 1916 r. doszło do reorganizacji NKN i ponownego wstapienia do niego części grupy podolaków, Jaworski uspokajał hr. Zdzisława A. Tarnowskiego, że „gdyby Podolacy i centrowcy chcieli na pierwszym posiedzeniu NKN przypuścić szturm w sprawie werbunku, to rzecz się odroczy" 48 .

Teodorowicz twierdził, że dla sojuszu z socjalistami konserwatyści krakowscy zeszli na drogę radykalizmu i teraz już trudno odróżnić na łamach „Czasu” ideologię konserwatywną od ideologii „Naprzodu”49. Pozwolił sobie na szczyt złośliwości, komentując działania konserwatystów w celu „wybielenia” socjalistów, zauważając, że niedługo roztoczą wizje, w których „rzesze czerwone zamiast pieśni o czerwonym sztandarze, będą niedługo już śpiewać hymn Serdeczna Matko"50. Stawiany przez Teodorowicza zarzut Jaworskiemu, „że idzie na pasku” socjalistów, nie do końca wydawał się słuszny, bowiem ten ostatni potrafił dla dobra sprawy narodowej nieraz ostro ich napiętnować, wskazując na szkodliwość podejmowanych przez nich działań ${ }^{51}$.

Naginanie prawa, lawirowanie i kłamstwa to według abp. Teodorowicza główne metody działania NKN. Zarzucał mu, że do realizacji własnych celów świadomie wprowadza w błąd społeczeństwo polskie. Jako przykład perfidnej gry Komitetu podał przemówienie Jaworskiego, wygłoszone we Lwowie 13 VI 1916 r., w którym wiceprezes NKN mówił: „Jesteśmy w ciagłym kontakcie z Królestwem. I tu zapewnić zaś mogę, że tam rozumieją nasze stanowisko i nie uczynią nic, co by je osłabiło"52.

Bardzo ostro abp Teodorowicz piętnował wykorzystywanie kobiet przez polityków hołdujących kiedyś zasadom trójlojalizmu, które dzięki temu, iż

\footnotetext{
${ }^{47}$ J. Teodorowicz, Stańczyk bez Teki..., s. 81.

${ }_{48}$ ANK, ADzT, sygn. 1127, W.L. Jaworski do Z.A. Tarnowskiego, Kraków 24 IV 1916, s. 427.

49 J. Teodorowicz, Stańczyk bez Teki..., s. 69-70.

50 Ibidem, s. 62.

${ }^{51}$ ANK, ADzT, sygn. 1127, W.L. Jaworski do Z.A. Tarnowskiego, Kraków 27 IX 1916, s. 513.

${ }^{52}$ J. Teodorowicz, Stańczyk bez Teki..., s. 69.
} 
„polityka jest [im] obca, nie znając arkanów polityki bieżącej”, łatwo stają się ofiara w rękach doświadczonych graczy politycznych. Przez zbieranie składek na cele polityczne organizacji, werbunek ideowy dla niej czy też przez sam fakt przynależności do NKN współtworzą one politykę, mimo iż jego cele nie są im bliżej znane ${ }^{53}$.

Teodorowicz podejmował starania, aby ograniczyć wpływy NKN i zapobiec poszerzeniu go o kolejne ugrupowania. Po rozpadzie Komitetu w październiku 1914 r. i likwidacji sekcji wschodniej abp Teodorowicz wraz z bp. Adamem S. Sapiehą byli przeciwni ponownemu wstapieniu podolaków do Komitetu i czynili zabiegi, aby temu zapobiec. Popierali go w tych działaniach czołowi działacze podolaków, tacy jak Aleksander Krzeczunowicz ${ }^{54}$. Arcybiskup Teodorowicz utrzymywał ścisłe kontakty z konserwatywnymi politykami Królestwa Polskiego, m.in. ze Stronnictwa Polityki Realnej i Stronnictwa Demokratyczno-Narodowego. Wspierał działalność powstałego w sierpniu 1915 r. Międzypartyjnego Koła Politycznego ${ }^{55}$. Jako człowiek o tak wybitnej osobowości i zarazem doświadczony działacz na polu politycznym odgrywał w tym środowisku znaczaca rolę. Tym bardziej że, jak twierdził Jaworski, „politycy konserwatywni Królestwa nie maja programu politycznego i nie

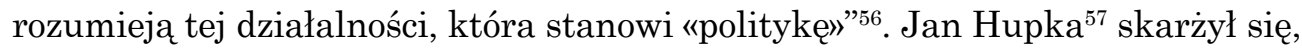
że po rozpadzie $\mathrm{NKN}^{58}$ Teodorowicz wraz bp. Sapiehą przekonywał w Wiedniu konserwatystów wschodniogalicyjskich na czele z księciem Witoldem Czartoryskim, aby do NKN nie wstępowano ${ }^{59}$. Jak jednak wynika $z$ listu pisanego do bp. Sapiehy przez Witolda ks. Czartoryskiego, to właśnie ten ostatni był

53 Ibidem, s. 64.

${ }^{54}$ W.L. Jaworski, Diariusz 1914-1918, wybór i oprac. M. Czajka, Warszawa 1997, s. 75-76, 80.

${ }^{55}$ Organizacja polityczna utworzona w październiku 1915 r., działająca do 1918 r. na terenie Królestwa Polskiego. W 1918 r. nawiązała współpracę z Radą Regencyjną i Komitetem Narodowym w Paryżu. W różnym czasie w jej skład wchodziły następujące ugrupowania polityczne: Stronnictwo Polityki Realnej, Stronnictwo Demokratyczno-Narodowe, Zjednoczenie Postępowe, Polska Partia Postępowa, Grupa Pracy, Zjednoczenie Narodowe, Stronnictwo Chrześcijańskiej Demokracji, Związek Niezależności Gospodarczej. Ostatecznie z Koła wystapiła Grupa Pracy.

56 Jaworski ubolewał, że żałują oni kompromisu z lewicą i są w złych relacjach z Ligą Państwowości Polskiej. ANK, ADzT, sygn. 1127, W.J. Jaworski do Z.A. Tarnowskiego, s. 190-193.

57 Jan Antoni Ernest Hupka - ziemianin, polityk związany z konserwatystami krakowskimi. Delegat NKN do rozmów z ugrupowaniami politycznymi z Królestwa Polskiego.

${ }^{58}$ Narodowi demokraci i podolacy podjęli decyzję o rozwiązaniu Legionu Wschodniego i 20 X 1914 r. wystapili z NKN, jako powód podając rozbieżność w sprawach zasadniczej polityki narodowej i niedotrzymanie umowy z 16 VIII 1914 r. - m.in. w sprawie formowania Legionów, ich zależności od armii austriackiej i nieprowadzenia werbunku na terenie Królestwa Polskiego. W. Suleja, op. cit., s. 42-92.

${ }^{59}$ Przeciwna wstapieniu podolaków była grupa Centrum (T. Cieński i W. Czartoryski) - za warunek uznawała powrót endecji i grupy „Rzeczypospolita”, a na to nie godzili się konserwatyści krakowscy. Ostatecznie doszło do rozłamu i do NKN wstapiła część podolaków z hr. Augustem Krasickim. A. Wątor, Chrześcijańsko-narodowi..., s. 110; J. Hupka, op. cit., s. 149. 
na początku 1915 r. nieprzejednanie przeciwny uleganiu żądaniu, aby pięciu przedstawicieli konserwatystów wstapiło do NKN. Książę wyraźnie informował Sapiehę, że dopuszcza taką możliwość jedynie wtedy, gdy „będzie spisany układ, że kasuje się całą działalność w Królestwie i zabrania się akcji politycznej"60. Teodorowicz opracował nawet referat, w którym wyłożył główne powody, dla których konserwatyści wschodniogalicyjscy nie powinni ponownie wstępować do $\mathrm{NKN}^{61}$, wskazując przy tym na niebezpieczeństwo planów konserwatystów krakowskich co do Jana Stapińskiego ${ }^{62}$ i Władysława Długosza ${ }^{63}$. Ten ostatni był według abp. Teodorowicza zainteresowany odegraniem w PSL „Piast” pierwszych skrzypiec, dlatego też należałoby to wykorzystać i wejść w porozumienie z Długoszem, ale tylko wtedy, jeśli usunięci zostaną ze współpracy „agitatorzy ludowi” (arcybiskup miał na myśli Stapińskiego i Daszyńskiego) ${ }^{64}$. Na wieść o rokowaniach pomiędzy NKN a Kołem Polskim abp Teodorowicz wraz z bp. Sapiehą przekonywali na początku 1916 r. w Wiedniu prezesa Koła Polskiego Leona Bilińskiego, aby wystapił przeciwko paktowi NKN z Kołem Polskim. Głównym powodem była niechęć do socjalistów, których biskupi nie chcieli widzieć w Kole. Ostatecznie jednak oświadczyli, że episkopat galicyjski

${ }^{60}$ Archiwum Kurii Metropolitarnej w Krakowie (dalej: AKMK), Teki Sapiehy (dalej: TS), sygn. V/179, List W. Czartoryskiego do bp. A.S. Sapiehy w sprawie stosunku konserwatystów do NKN, Wiedeń 23 II 1915. Jak wynika z tego listu, przeciwna ponownemu wstapieniu do NKN była większość konserwatystów. Por. też: ANK, NKN, sygn. 77, MF 100, 267, List W. Czartoryskiego do L. Bilińskiego z 15 III 1916, k. 59-61.

${ }^{61}$ Najprawdopodobniej jest to anonimowy tekst przesłany do bp. A.S. Sapiehy, którego zniszczenia, w przypadku gdyby sprawy przybrały niepomyślny obrót, domagał się abp Teodorowicz (AKMK, TS, sygn. V/195). W referacie, który może być autorstwa Teodorowicza bądź kogoś z jego otoczenia, wskazano, że obecnie nie ma żadnego realnego celu we wstępowaniu do NKN (kiedyś była nim ucieczka przed werbunkiem poprzez stworzenie Legionów). Komitet tworzą ludzie, którzy publicznie przyznają się, że nie zamierzają dotrzymywać zobowiązań i umów (świadczyć o tym miały artykuły K. Srokowskiego w „Nowej Reformie”). Wobec bezpośredniego podlegania Departamentu Wojskowego NKN austriackiemu dowództwu wojskowemu nie będzie można się przeciwstawić bezsensownemu poborowi rekruta w Królestwie. Wobec zaś doświadczeń losu, jaki spotkał Stanisława Strońskiego i Tadeusza Cieńskiego, można przypuszczać, iż to samo przydarzy się każdemu, kto będzie chciał przeciwstawić się polityce NKN. Z powodu rozwijającej się sytuacji politycznej w kraju i wzrastającego fermentu społecznego, wynikającego ze sprzeciwu wobec coraz bardziej jednostronnych tendencji w NKN i jego polityki, należy przypuszczać, iż w niedalekiej przyszłości wszyscy, którzy w jakikolwiek sposób będą związani z NKN, staną się „politycznymi trupami”. AKMK, TS, sygn. V/208.

${ }^{62}$ Pod koniec 1915 r. konserwatyści galicyjscy chcieli rozszerzyć platformę Koła Polskiego w Wiedniu i pragnęli wciagnąć do niego PSL-Lewicę i Jana Stapińskiego oraz uzyskać ich poparcie dla posunięć NKN.

${ }^{63}$ W sierpniu 1914 r. wszedł do NKN z ramienia PSL „Piast”, jednak nie wykazywał większego zainteresowania jego działalnościa, a jego reprezentanci nie pojawiali się na obradach.

${ }^{64}$ AKMK, TS, sygn. V/195, List abp. J. Teodorowicza do bp. A.S. Sapiehy w sprawie stosunku konserwatystów do NKN. W ostateczności Długosz, który na wsi nie miał szans wygrać z wpływami Stapińskiego, zdecydował się na związanie z ND i episkopatem galicyjskim. 
nie weźmie udziału w zabiegach czynionych na rzecz zjednoczenia, bo nie chce się mieszać $\mathrm{w}$ sprawy polityczne i brać odpowiedzialności za rzeczy, na które nie będzie miał wpływu ${ }^{65}$.

Na rokowania, jakie prowadziło Koło Polskie z NKN w celu ujednolicenia kierownictwa spraw polskich i spowodowania współdziałania wszystkich stronnictw w „pracy narodowej”, abp Teodorowicz patrzył podejrzliwie. Zarówno jego, jak i część innych biskupów galicyjskich nie przekonywały argumenty prezesa Koła Polskiego Leona Bilińskiego i nie zdecydowali się oni na zadośćuczynienie jego prośbie, aby wytypować swoich dwóch przedstawicieli majacych zasiaść w zreorganizowanym $\mathrm{NKN}^{66}$. Arcybiskup Teodorowicz twierdził, że Komitetowi zależało tylko na tym, aby biskupi użyczyli jego politykom swojego autorytetu i pobłogosławili pastorałem wszystkie posunięcia ${ }^{67}$. Teodorowicz wiedział, że działacze NKN nazywali go złym duchem episkopatu, bardzo często używając wobec niego określenia ks. „Teodos”68.

Arcybiskup Teodorowicz nigdy nie wierzył w szczerość intencji konserwatystów krakowskich, zaś w 1916 r. uważał, że rzucili oni hasło zjednoczenia (do którego miało dojść 29 kwietnia), by pod ta przykrywką szukać rozgrzeszenia dla swoich kompromisów i „łudzić swoje narodowe sumienie i innych"69. Arcybiskup miał sporo racji, bowiem potwierdzenie jego słów można znaleźć w wywiadzie przeprowadzonym z Leonem Bilińskim $25 \mathrm{~V}$ 1916 r., w którym prezes Koła Polskiego przyznawał, że wprawdzie kanclerz niemiecki, mimo wcześniejszych przyrzeczeń, nie chce teraz zgodzić się na oddanie Królestwa Polskiego Austro-Węgrom, „można przecież być pewnym, że jeszcze przed końcem wojny nastapi uregulowanie kwestii polskiej w myśl życzeń Austro-Węgier i programu Koła polskiego oraz NKN"70.

Układ zawarty pomiędzy Kołem Polskim w Wiedniu i NKN miał na celu ujednolicenie kierownictwa polityki i określał wzajemny zakres działania. Jak stwierdzono, dla spełnienia swojego zadania, tj. stworzenia Legionów, Komitet musi ,jednać wyznawców idei legionowej, torującej drogę do rozwiązania sprawy polskiej"11. Zezwolono NKN na tworzenie w Galicji organizacji dla agitacji za programem legionowym - w tym celu mógł wydawać różnego rodzaju pisma i broszury, prowadzić poprzez Departament Wojskowy akcję

${ }_{65}$ AKMK, TS, sygn. V/203, List Episkopatu Galicji do L. Bilińskiego w sprawie stosunku do NKN, s. 3-4.

${ }^{66}$ AKMK, TS, sygn. V/197, List L. Bilińskiego do abp. Bilczewskiego z prośbą o delegowanie dwóch katolików do NKN.

${ }^{67}$ AKMK, TS, sygn. V/200, List abp. J. Teodorowicza do bp. A.S. Sapiehy w sprawie listu L. Bilińskiego, [b.m.] 14 III 1916.

68 AKMK, TS, sygn. V/ 220, List abp. J. Teodorowicza do bp. A.S. Sapiehy w sprawie jego stanowiska wobec konserwatystów.

${ }^{69}$ APO, Teodorowicz, t. 117, sygn. 428/217[6], Pisma polityczne dotyczące NKN, k. 70.

${ }^{70}$ Rozmowa dziennikarza A.N. $z$ dr Leonem Bilińskim $w$ dniu 15 maja 1916, „Z Dokumentów Chwili”, 20 XII 1916, nr 9, seria VI, s. 47-48.

${ }^{71}$ AKMK, TS, sygn. V/233, Układ pomiędzy Kołem Polskim a NKN, 1916 [b.m.]. 
werbunkowa, samoistnie porozumiewać się w sprawach legionowych z rządem i $\mathrm{AOK}^{72}$. Na Kole Polskim spoczywało kierownictwo spraw polskich „ogólnonarodowych". Obejmowało to rokowania z wszelkimi władzami państwowymi (także zagranicznymi), rokowania ze stronnictwami austriackimi i węgierskimi oraz reprezentantami polskich kół politycznych z innych dzielnic. Ustalono, iż do komisji politycznej Koła Polskiego będą powołani czwarty członek Izby Panów oraz zasiadający w Kole Polskim reprezentanci stronnictwa socjalno-demokratycznego i dawnych organizacji militarnych. Wspólnie zdecydowano, iż zostanie zmieniony skład NKN. Stronnictwa konserwatywne, które w październiku 1914 r. opuściły NKN, zajmą sześć miejsc w Komitecie i jedno miejsce w komisji wykonawczej. Utworzony zostanie urząd wiceprezesa, który obejmie dotychczasowy prezes Władysław Leopold Jaworski, zaś prezesem NKN będzie prezes Koła Polskiego Leon Biliński ${ }^{73}$.

Prezes Koła Polskiego Biliński w opublikowanym liście do Zdzisława Adama hr. Tarnowskiego (datowanym na $8 \mathrm{~V}$ 1916) uznał, że niewzięcie udziału przez biskupów krakowskich w zjeździe krakowskim 29 IV 1916 r., którego cel stanowiła reorganizacja NKN, podyktowane było pobudkami politycznymi. Biliński stwierdził w nim, że biskupi stali się narzędziem w rękach partii politycznych z Królestwa, a bp Stanisław Pelczar - „"Zwolennik akcji zjednoczenia tak rzadkiej niestety w Polsce» również uległ politycznej presji”74. W zawoalowanych słowach oskarżył abp. Teodorowicza, że jeździł on do Warszawy w celach najprawdopodobniej politycznych i wypowiedziana przez niego opinia przyczyniła się do wycofania się bp. Pelczara z wzięcia udziału w zjeździe. Biskupi zaprotestowali przeciwko takiemu publicznemu przedstawianiu wydarzeń, oświadczając, iż abp Teodorowicz pojechał do Warszawy jedynie $\mathrm{w}$ sprawach kościelnych i religijnych (co niezgodne z prawda) i że nie było z Królestwa (ani ze strony partii politycznych, ani z osób publicznych) żadnych wystapień do episkopatu galicyjskiego w sprawie stosunku do $\mathrm{NKN}^{75}$. Według opinii części współczesnych działaczy politycznych ta interwencja abp. Teodorowicza zakwestionowała dojście do skutku zgody $\mathrm{w}$ instytucjach narodowych ${ }^{76}$.

Różnoraki stosunek do Legionów był następstwem niejasno określonych od samego początku charakteru i celów Legionów - inaczej zapatrywał się na nie rząd austriacki i komenda wojskowa austriacka, inaczej ci, którzy je faktycznie tworzyli (ich poglądy też się różniły), a jeszcze inaczej sami legioniści. Nie do pogodzenia stał się fakt, że Legiony potraktowano jako

\footnotetext{
${ }^{72}$ Armeeoberkommando - Naczelne Dowództwo Austriackie.

${ }^{73}$ AKMK, TS, sygn. V/233, Układ pomiędzy Kołem Polskim a NKN, (?) 1916.

${ }^{74}$ AKMK, TS, sygn. V/203, List Episkopatu Galicji do L. Bilińskiego w sprawie stosunku do NKN.

${ }^{75}$ Ibidem.

76 M. Sokolnicki, Rok czternasty, Londyn 1961, s. 372 (dokument pt. Memorandum konserwatystów krakowskich).
} 
rodzaj pospolitego ruszenia, podległego komendzie austriackiej. Udzielając 27 VIII 1914 r. zgody na utworzenie dwóch Legionów (Wschodniego we Lwowie i Zachodniego w Krakowie), Naczelna Komenda Armii obwarowała go 16 warunkami i zastrzeżeniami ${ }^{77}$. Po rozwiązaniu Legionu Wschodniego i wystapieniu z NKN podolaków i narodowych demokratów, oskarżono tychże o zdradę stanu, domagając się przykładnego, surowego ich ukarania ${ }^{78}$. Internowano Tadeusza Cieńskiego, a oskarżonego o defraudację pieniędzy ze skarbu wojskowego Aleksandra Skarbka uchronił przed takim losem wyjazd do Szwajcarii ${ }^{79}$. Teodorowicz bronił Cieńskiego, podkreślając, że nie słuchano jego argumentów i że nie można mu zarzucać od początku celowego dążenia do rozwiązania Legionu Wschodniego, „bo jest na taką komedię za porządnym człowiekiem" ${ }^{80}$. Arcybiskup nie mógł przeboleć, że sprawa Legionu Wschodniego stała się pretekstem do zatajenia prawdziwych powodów konfliktu w łonie NKN, a rzucenie oszczerstw na wyżej wymienione partie polityczne i zarzucenie im zdrady ${ }^{81}$ spowodowało $\mathrm{w}$ monarchii austriackiej nie tylko spadek zaufania do wschodniej części kraju i ułatwienie agitacji wrogim narodowi polskiemu czynnikom, ale również zmianę opinii w najwyższych sferach państwa na temat lojalności narodu polskiego ${ }^{82}$.

Teodorowicz nie chciał, aby wspaniała młodzież polska, która kierując się porywem serca i idąc za hasłami rzuconymi przez polityków, wstępowała do Legionów, była traktowana przez AOK jako mięso armatnie ${ }^{83}$. Zatrważające

77 S. Głąbiński, op. cit., s. 214-215.

${ }^{78}$ „Pod sąd z takimi politykami, którzy Targowicy śladami, a dla obrony Rzeczypospolitej [podkreślenie oryginalne - R.K.M.] z Moskwą weszli w konszachty [...]. W obliczu kroczących na Warszawę strzelców Piłsudskiego w obliczu wszystkich ofiar, jakie ponosimy i ponosić będziemy dla narodowej sprawy pod SĄD POLSKI POWSTAJĄCEJ powołujemy pp. Cieńskiego i Skarbka i ich współpracowników, jako winnych zbrodni stanu względem Narodu Polskiego!!!” Biblioteka Narodowa, rkps IV 5502, Pod sqd! [Historia Legionu Wschodniego], Sosnowiec 1914, s. 20-21.

79 S. Głąinínski, op. cit., s. 221-222.

${ }^{80}$ CDIAUL, Fond 475, opis 1, spr. 54, Pisma z historii i religii abp J. Teodorowicza, k. 155.

${ }^{81}$ Arcybiskup Teodorowicz uważał, że socjalistów i konserwatystów krakowskich w walce z podolakami i endekami zespalała nienawiść „do żywiołów umiarkowanych, wolnych od przeskoków politycznych i prowadzących jednolicie ciagła politykę czysto narodową bez klasowego zabarwienia”. J. Teodorowicz, Stańczyk bez Teki..., s. 102.

${ }^{82}$ Ibidem, s. 82-83.

${ }^{83}$ Arcybiskup zapewne solidaryzował się ze słowami wyrażonymi w apelu z 10 XI 1914 r., podpisanym przez czołowe osobistości Lwowa, w tym polityków związanych z nurtem chrześcijańskim, ND i podolakami, m.in. M. Thulie, M. Ernsta, S. Grabskiego, S. Kasznicę, J. Gwalberta-Pawlikowskiego, L. Pinińskiego. W odezwie tej stwierdzano, że wobec zaistniałych wypadków i jednoznacznie wyrażonej opinii przez ugrupowania polityczne w Królestwie Polskim dalsze istnienie osobnych oddziałów ochotniczych nie odpowiada interesom narodowym, dlatego też Drużyny Sokole, Bartoszowe i Strzeleckie, z których zamierzano stworzyć Legion Wschodni, rozwiązały się. Młodzież ta jednak nie uciekała od walki i została włączona w szeregi armii austriackiej. Wyrażono przekonanie, iż Legion Zachodni, podlegający wpływom socjalistycznym, również powinien ulec rozwiązaniu, a ci 
doniesienia $\mathrm{z}$ frontu tylko ugruntowywały w nim to przekonanie. Bogdan Krzysztofowicz (pochodzenia ormiańskiego), urzędnik kolejowy będący w kierownictwie transportów polowych we Lwowie, pisał, że w pierwszym miesiącu wojny Austriacy „na otwarte, nie okopane pola rzucali wojska jak na manewrach i tracili całe pułki” ${ }^{4}$. Po latach abp Teodorowicz wspominał:

To zaś, co Austria zamierzała z Legionami, to było rzeczą wprost zbrodniczą i potworna. Bo planem Austrii było użyć legionistów polskich do wywołania powstania na tyłach Rosji. Przez taki plan Austria poświęcała dla swoich celów kwiat młodzieży polskiej, nie uznawanej przez Moskali za regularne wojsko, a więc bez miłosierdzia rozstrzeliwanej i skazywała na najokropniejszy los ludność polską w miejscach, gdzieby powstanie wybuchło. Bo w razie cofnięcia się wojsk austriackich, ludność byłaby zdana na zemstę Rosji ${ }^{85}$.

Arcybiskup nie mógł wybaczyć działaczom NKN, że potępiając rozwiązanie Legionu Wschodniego wskutek tekstu przysięgi, formalnie zatwierdzili stanowisko Austrii w tej sprawie.

Teodorowicz bardzo ostro krytykował werbunek do Legionów przeprowadzany na terenie Królestwa Polskiego, nazywajac go „branka”. Wykazywał w tym wypadku obłudę polityków NKN, bowiem werbunek był niezgodny z umową zawartą przez stronnictwa 16 VIII $1914 \mathrm{r}$. Wskazywał, że właśnie chęć zneutralizowania zakusów werbunkowych skłoniła ugrupowania wschodniogalicyjskie do przystapienia do NKN. Kwestia werbunku w Królestwie była według arcybiskupa głównym powodem rozłamu w NKN i uniemożliwiała powtórne przystapienie do niego ugrupowań wschodniogalicyjskich ${ }^{86}$.

Na negatywny stosunek do poboru rekruta do Legionów na pewno jakiś wpływ miały doniesienia składane biskupom, w których szczegółowo opisywano, jak wyglądała ta akcja. Ponieważ werbunek do Legionów w Galicji i w innych krajach monarchii został wstrzymany od dnia 1 XI 1914 r., akcja musiała zostać przeniesiona na teren Królestwa. W wyniku kroków podjętych przez NKN i władze wojskowe Legionów, dotyczących zgody na uzupełnianie formacji Legionów na terenie Królestwa, z początkiem grudnia $1914 \mathrm{r}$. austriackie naczelne władze wojskowe powierzyły płk. Władysławowi Sikorskiemu prowadzenie werbunku uzupełniającego na wyżej wskazanym terenie. Według doniesień z gminy Bolesław werbunek rozpoczynano od uroczystości patriotycznych lub rocznicowych, po których miały miejsce tzw. mowy do

ludzie, którzy nie zostaną wcieleni do armii, winni powrócić do normalnych zajęć, z których „w tych trudnych i ciężkich warunkach lepsze mogą oddać usługi”. ANK, NKN, sygn. 80, MF 100, 270, s. 27-28.

${ }^{84}$ Biblioteka Lwowskiego Uniwersytetu Narodowego im. Iwana Franka (dalej: BLUN), rkps 1492 III, B. Krzysztofowicz, Zapiski wojenne. Notatki pisane w czasie wojny 1914-1918, k. 1.

${ }^{85}$ Interview z JE.X. Arcybiskupem Józefem Teodorowiczem $w$ jesieni 1927 r. z okazji Jego jubileuszu srebrnego biskupstwa, w: R. Król-Mazur, Działalność polityczna..., s. 180.

${ }^{86}$ APO, Teodorowicz, t. 117, sygn. 428/217[6], Pisma polityczne dotyczace NKN, k. 23, 35, $70,78$. 
uczucia, w których padały niejednokrotnie takie sformułowania, jak: „Polak nie może czekać bezczynnie, ma iść i bić Moskala, wszyscy, którzy nie pójda, to psy" ${ }^{87}$. Posuwano się również do składania obietnic - rodzinie każdego, kto dobrowolnie wstapi do Legionów miało być wypłacane 10 koron, a następnie pewna kwota miesięcznie; wraz z tym dostarczane mąka, kasza, cukier i słonina. Kiedy to nie pomogło, pod zarzutem włóczęgostwa chwytano ludzi na drogach, nie wahając się strzelać do uciekających. Wobec marnych rezultatów tej metody zaczęto zabierać mężczyzn z domów w środku nocy. Do momentu pobytu Legionów na danym terenie ludność nie mogła nawet głośno mówić o ich „ekscesach”, bowiem groziło to oskarżeniem o bycie agentem moskiewskim $^{88}$. Teodorowicz uważał, że gdyby NKN, któremu ludność również skarżyła się „na wybryki i nadużycia dokonywane pod firmą ideologii legionowej”, od razu napiętnował takie zachowanie, to uchroniłby się od posądzenia o solidaryzowanie się z nimi i zapobiegł podobnym nadużyciom $\mathrm{w}$ przyszłości ${ }^{89}$.

Teodorowicz nie bał się krytykować przywódców politycznych za wykorzystywanie żołnierzy do realizacji swoich celów politycznych - znajdował posłuch zwłaszcza w sferach ziemiańskich. Jak narzekał Jaworski, „uciera się w społeczeństwie przekonanie, że szlachta jest wroga Legionom i że odcina się od narodu. Jest to opinia, która grozi katastrofa" ${ }^{90}$.

Arcybiskup oburzał się na postępowanie polityków krakowskich, którzy według niego od początku wszystkich okłamywali - za skandaliczne uważał składane w Wiedniu zapewnienia o wywołaniu powstania w Królestwie i dostarczeniu rekruta. Bardzo negatywnie oceniał wybór Jaworskiego do komisji politycznej Koła Polskiego, sarkastycznie stwierdzając: „i dzięki tym osobliwym przesunięciom, to wszystko, w czem przewini przypadkiem politycznie p. Jaworski i jego grupa w Komitecie Naczelnym, to rozgrzeszy i umywa tenże sam p. Jaworski w Centralnym Komitecie i deklaruje notabene etykietę Koła Polskiego" ${ }^{\text {. }}$.

Teodorowicz sprzeciwiał się działaniom podejmowanym przez bp. Władysława Bandurskiego ${ }^{92}$. Najprawdopodobniej główną przyczynę tego stanowiło

${ }^{87}$ AKMK, TS, sygn. V/232, Sprawozdanie ze scen przy werbunku do Legionów, luty 1916.

88 Ibidem.

89 J. Teodorowicz, Stańczyk bez Teki..., s. 75.

${ }^{90}$ ANK, ADzT, sygn. 1127, W.L. Jaworski do Z.A. Tarnowskiego, Kraków 30 VI 1915, s. 357.

${ }^{91}$ APO, Teodorowicz, t. 117, sygn. 428/217[6], Pisma polityczne dotyczące NKN, k. 23, 35, $70,78$.

92 Jeszcze przed wybuchem wojny angażowanie się bp. Bandurskiego w akcje patriotyczne sprawiało wiele kłopotów biskupom galicyjskim i było przedmiotem troski abp. Teodorowicza i abp. Bilczewskiego: „Doszliśmy do wniosku, że jego akcja, w której wciąż prawi o dąż[eniu] do Polski niepodległej jest w najwyż[szym] stopniu szkodliwa dla Kościoła i narodu, bo podnieca, potęguje dzisiejsze podniecenie patriotyczne - szkodzi nam w Rosji, Prusiech, Wiedniu, Rzymie”. Cyt. za: ks. J. Wołczański, Listy arcybiskupa Józefa Teodorowicza do arcybiskupa Józefa Bilczewskiego z lat 1900-1923, cz. 2: 1902-1913, „Przegląd Wschodni” 2004/2005, t. IX, z. 2 (34), s. 416. 
wywyższenie bp. Bandurskiego, który przez komendy austriackie traktowany był jako biskup polowy Legionów, a przez legionistów witany jako przyszły prymas Polski. Wśród polityków związanych z NKN panowało przekonanie, że abp Teodorowicz wraz z bp. Sapiehą interweniował w AOK, aby wydało zakaz bp. Bandurskiemu jeżdżenia na front do Legionów i do Królestwa ${ }^{93}$. Bandurski zdawał sobie sprawę z poczynań swoich lwowskich kolegów, pisząc w obronie płk. Sikorskiego: „A przecież gdyby nie zabiegi pułkownika, kto wie coby się stało z Legionami! Wobec intryg hrabiów, książąt i biskupów przedstawiających w AOK i na dworze [cesarskim - R.K.M.] Legiony nasze, jako bandę socjalistyczną" ${ }^{4}$.

Komitet zabiegał o pozyskanie episkopatu galicyjskiego, kiedy jednak duchowieństwo nie zdecydowało się dać swoich dwóch delegatów, przypuszczono na nie ataki, zarzucając mu, iż miesza się do polityki ${ }^{95}$. Teodorowicz ostrzegał działaczy NKN, aby nie podejmowali działań w celu rozbicia solidarności episkopatu galicyjskiego ${ }^{96}$ (próba pozyskania bp. Pelczara ${ }^{97}$ ), bo to jedynie może jeszcze bardziej zrazić biskupów do nich ${ }^{98}$. Kościół przecież był czynnikiem integrującym Polaków, jednoczył naród po rozbiorach. Stanowił źródło, z którego w trudnych czasach Polska czerpała siły do życia ${ }^{99}$. Arcybiskup stawiał znak równości pomiędzy katolicyzmem a słuszną sprawą narodowa. Dla niego „Rząd duchowy” stanowił rząd narodowy, a rozdzielony naród łączył episkopat ${ }^{100}$.

${ }^{93}$ J. Hupka, op. cit., s. 149. Abp Teodorowicz zaprzeczał tym stwierdzeniom. J.T. Teodorowicz, Naczelne rysy charakteru księcia metropolity Sapiehy, w: Dwadzieścia pięć lat pasterzowania księcia metropolity Adama Stefana Sapiehy. Księga jubileuszowa, Kraków 1937, s. 19.

${ }^{94}$ Biblioteka Ukraińskiej Akademii Nauk we Lwowie im. Wasyla Stefanyka (dalej: BUANL), Oddział Rękopisów, zespół Ossolińskich (dalej: Ossol.), opis 1, rkps 6910, List ks. bp. W. Bandurskiego z powodu ataków na płk. W. Sikorskiego, Wiedeń 2 XII 1915, s. 167.

95 J. Teodorowicz, Stańczyk bez Teki..., s. 12.

${ }^{96}$ Według J. Hupki abp. Bilczewski był niechętnie nastawiony do bp. Sapiehy oraz abp. Teodorowicza. W.L. Jaworski, op. cit., s. 107. To ostatnie spostrzeżenie okazało się jednak całkowicie fałszywe. Jak wiadomo, obydwu hierarchów łączyła długoletnia przyjaźń, choć obaj nie szczędzili sobie różnych drobnych złośliwości.

${ }^{97} \mathrm{Na}$ zebraniu Koła Sejmowego 29 IV 1916 r. miało dojść do zreorganizowania NKN, poszerzenia jego zaplecza politycznego i doprowadzenia do zgody wszystkich stronnictw. Działaczom NKN zależało, aby w obradach wzięli udział biskupi galicyjscy. Pelczar uważał, iż biskupi powinni uczestniczyć w tych obradach i jasno określić zasady współdziałania stronnictw polskich w oparciu o principia katolickie i z pożytkiem dla Kościoła i narodu. Proponował wejście abp. Teodorowicza do komisji politycznej NKN i oddelegowanie reprezentanta episkopatu galicyjskiego do Komitetu, aby ten mógł zajać się Legionami. Biskupi jednak nie wzięli udziału w krakowskich obradach 29 kwietnia. Do Krakowa przybył bp Pelczar, ale nie uczestniczył w posiedzeniu Koła Sejmowego, choć jak sam podkreślał, zrobił to, by uszanować wolę biskupów, bowiem sam miał odmienny pogląd w tej sprawie.

R. Król-Mazur, Działalność polityczna..., s. 74-75.

98 J. Hupka, op. cit., s. 205.

99 J. Teodorowicz, Myśl religijna w narodzie, Londyn 1943, s. 4.

${ }^{100}$ Idem, Pierwiastek nadprzyrodzony a dzisiejsza doba Polski, Warszawa 1907, s. 50. 
Arcybiskup Teodorowicz uważał, że „piekło”, które rozpętało się w 1914 r., miało być nauczką dla współczesnego człowieka, który był tak zadufany w swoich osiagnięciach, w rozwoju cywilizacji i kultury, że nie wierzył w możliwość wybuchu wojny, bowiem „układy międzynarodowe, zręczna gra dyplomatów talentem i rozumem wyrówna i ułoży międzynarodowe karty” ${ }^{101}$. Twierdził, że doszło do tych strasznych wydarzeń dlatego, że „polityka używała mnogich kruczków do usunięcia problemów narodowych", głosiła hasło siły przed prawem, które zapanowało wszechwładnie w tzw. realnej polityce - „pozwalało łamać dekalog, żyć kłamstwem i marnym szalbierczym rachunkiem z pogwałceniem zasad" ${ }^{102}$. Arcybiskup Teodorowicz ubolewał nad ofiarą przelanej krwi żołnierzy - synów polskich ze wszystkich trzech zaborów, obawiając się, czy „zimna, obliczając[a] po kupiecku Europa nie zapisze naszego wyczerpania i licznych strat jako słabości?” Nie był też przekonany, czy ta ofiara „będzie dość silna, by zdusić sceptyczne poglądy w łonie naszego własnego społeczeństwa"103.

Teodorowicz oświadczał, że publicznie nie występował przeciwko Legionom, tylko przeciw Piłsudskiemu jako socjaliście ${ }^{104}$. Dla arcybiskupa młodzi ludzie, którzy rwali się do Legionów z miłości do ojczyzny, nie wiedząc, że sa oszukiwani przez państwa zaborcze, zostawali swoistymi męczennikami. Poddawani byli męczeństwu psychicznemu i moralnemu, gdyż werbujące ich instytucje „nieszczerze mówiły i o sobie tylko myślały” ${ }^{105}$. Arcybiskup w swojej słynnej mowie w Izbie Panów z 30 X 1917 r. grzmiał:

Było błędem nie uwzględniać psychologii serca młodzieńczego wojownika, które daremnie wyczekiwało na wcielenie w formę przysięgi tego ideału, za którym poświęcić się chciało. Było błędem, że podniecało się młodzież mglistymi frazesami, nie dając jednocześnie żadnych podstaw realnych pod słowa. Błędem było, że legiony stworzone w Galicji, oddane zostały nie państwu Polskiemu, ale gubernatorowi warszawskiemu. Skoro monarchia raz uznała Państwo Polskie, to nie należało oddawać Legionów nikomu innemu, jak tylko wyłącznie i jedynie Państwu Polskiemu ${ }^{106}$.

Aby skuteczniej przeciwstawić się poborowi rekruta i tworzeniu armii polskiej u boku Niemiec, abp Teodorowicz zaangażował się w prace Stefana Dąbrowskiego nad badaniem stanu wyczerpania rezerw demograficznych w państwach centralnych ${ }^{107}$. Celem tych badań było przeciwdziałanie

${ }^{101}$ CDIAUL, Fond 475, opis 1, spr. 57, Kazanie J. Teodorowicza (XXIV Dedykowane na Boże Narodzenie 25 XII 1915 r.), k. 215v.

102 Ibidem, Kazanie abp. J. Teodorowicza na Stary Rok (31 XII 1915 r.), k. 226.

${ }^{103}$ Ibidem, k. 227v.

${ }^{104}$ R. Król-Mazur, Działalność polityczna..., s. 75.

${ }^{105}$ Z. Pałubska, Duchowe przesłanie abp Józefa Teofila Teodorowicza w kazaniu sejmowym z 2 II 1919 r., „Rocznik Teologii Katolickiej” 2005, t. IV, s. 133; R. Król-Mazur, Działalność polityczna..., s. $185-187$.

106 Interview z JE.X. Arcybiskupem Józefem Teodorowiczem..., s. 187.

107 R. Król-Mazur, Działalność polityczna..., s. 75. 
ówczesnym tendencjom Departamentu Wojskowego NKN do werbunku lub przymusowego poboru rekruta w Królestwie. Józef Teodorowicz podczas wizyty w Warszawie zapoznał z hipotezami Dąbrowskiego środowisko tamtejszych aktywistów, m.in. Wojciecha Rostworowskiego ${ }^{108}$. Teodorowicz, podobnie jak Dąbrowski, uważał, że społeczeństwo polskie powinno zachować siły ludzkie dla własnego państwa. Społeczeństwo ówczesne było bardzo zróżnicowane w swojej postawie wobec Legionów i pomysłu organizowania armii polskiej u boku Niemiec. Uwidoczniało się szczególnie na terenie Królestwa Polskiego ${ }^{109}$.

Arcybiskup Teodorowicz w swoich wypowiedziach niejednokrotnie podkreślał męczeństwo żołnierzy ginących na froncie: „Śmiało rzec można, że Europa elitę swoja wysyła nie tylko na boje, ile na życia zaparcie się i wyrzeczenie w okopach: żyją tam żołnierze najczęściej bez dachu, w zimnie i błocie, które już nie depcza, ale wprost w nim mieszkaja”"110. O żołnierzach siedzacych w okopach arcybiskup pamiętał zawsze z okazji najważniejszych świąt kościelnych. W kazaniu na Boże Narodzenie 1915 r. podkreślał: „Myśmy w tę wojnę nie szli, ani jej szukali - myśmy w nią wciagnięci gwałtem i siłą wypadków. My jesteśmy ci, co najmniej się przyczyniając do jej wywołania, najwięcej w niej jednak cierpimy"111. W kazaniu wygłoszonym 15 VIII 1915 r. na święto Wniebowzięcia Matki Boskiej arcybiskup prosił, aby mieć szczególny szacunek dla ziemi, gdzie „błąka się po niej żałobne wspomnienie, bieleją ukryte w trawie pobojowisk czaszki, a krew zaprawia plony, co rosną i dojrzewaja" 112 .

Teodorowicz pośredniczył w przekazywaniu listów do papieża Benedykta XV z prośbami od mieszkańców guberni lubelskiej, członków rodzin żołnierzy wziętych na wojnie do niewoli o wstawiennictwo w sprawie ich zwolnienia $^{113}$. Sam arcybiskup najprawdopodobniej nie miał większych wpływów w otoczeniu papieża, bowiem, jak donosił Roman Dmowski w maju 1917 r., Ojciec Święty „wyrażał uznanie dla prac episkopatu polskiego [w tym i tych związanych z orientacją polityczna - R.K.M.] wymieniając imiennie X. biskupa Sapiehę, oraz arcybiskupa Kakowskiego"114.

108 J. Malinowski, Działalność polityczno-społeczna prof. Stefana Dabrowskiego (1877-1947), s. 42-44, https://repozytorium.amu.edu.pl/jspui/bitstream/10593/2650/1/Działalność\%20 polityczno-społeczna\%20Stefana\%20Dąbrowskiego.pdf (dostęp: 11 VII 2015).

109 Szerzej zob. J. Snopko, Społeczeństwo Królestwa wobec Legionów Polskich po akcie 5 listopada, w: Lata Wielkiej Wojny. Dojrzewanie do niepodlegtości 1914-1918, red. D. Grinberg, J. Snopko, G. Zackiewicz, Białystok 2007, s. 279-293.

${ }^{110}$ CDIAUL, Fond 475, opis 1, spr. 57, Kazanie abp. J. Teodorowicza, III-majowe (notowane), 14 V 1916 r., k. 241v-242.

${ }^{111}$ Ibidem, Kazanie abp. J. Teodorowicza XXIV (dyktowane) na Boże Narodzenie 25 XII 1915 , k. $221-221 \mathrm{v}$.

112 CDIAUL, Fond 475, opis 1, spr. 57, k. 183-183v.

${ }^{113}$ CDIAUL, Fond 475, opis 1, spr. 83, Prośba mieszkańców województwa lubelskiego skierowana do Benedykta XV, k. 1-120.

114 ANK, NKN, sygn. 105, MF 100, 295, Instrukcja Dmowskiego nadesłana z Agencji Lozańskiej do Koła Międzypartyjnego w Warszawie 15 V 1917, s. 346. 
Po zajęciu Królestwa Polskiego przez wojska państw centralnych abp Teodorowicz obawiał się, aby rządy i wpływy w Królestwie nie dostały się w ręce socjalistów. Zapewniał, iż sam będzie tam oddziaływał na prawicę ${ }^{115}$. W czasie swoich wyjazdów do Wiednia, które niejednokrotnie nosiły znamiona „misji dyplomatycznych”, potrafił tak przedstawiać nastroje w społeczeństwie polskim, aby uzyskać jak największe korzyści dla sprawy polskiej ${ }^{116}$. Sytuacja nie sprzyjała, bo jak wspominał Władysław Belina-Prażmowski, nawet wśród żołnierzy Legionów widać było „jawny upadek ducha. Z początku szli wszyscy bez zastrzeżeń. Po wzięciu Warszawy oczekiwały Legiony wyraźnego manifestu, jawnego postawienia sprawy [...] Tymczasem Austria nic pewnego nie mówi i ogranicza się na ogólnikach"117.

Kazimierz Świtalski uzasadniał słabość i brak poparcia społeczeństwa dla NKN wpływami obozu abp. Teodorowicza, Wysłoucha i rozbitków endecji ${ }^{118}$. Z tego też względu konserwatyści krakowscy czynili liczne zabiegi w celu pozyskania abp. Teodorowicza do idei Legionów i NKN. Zwracano mu uwagę, że nastapiła konsolidacja i do NKN należą też posłowie, do których ma zaufanie - podajac jako przykład związanego z konserwatystami wschodniogalicyjskimi hr. Aleksandra Dąmbskiego ${ }^{119}$, z którym abp Teodorowicz współpracował przeciwko blokowi namiestnika Bobrzyńskiego ${ }^{120}$. O względy arcybiskupa zabiegała też część Sztabu Komendy Legionów niezadowolona z polityki NKN i jego Departamentu Wojskowego ${ }^{121}$. Ostatecznie z Departamentu miało wystapić 60 członków ${ }^{122}$.

Za swą odważną działalność polityczną i narodową w początkowym okresie wojny abp Teodorowicz został umieszczony w $1915 \mathrm{r}$. przez austriacki wywiad wojskowy, jako czołowa osobistość, na liście Polaków ze „sfer lepszych”, przeciw którym wdrożono z rozkazu gen. Letofsky'ego śledztwo wojskowo-sądowe

115 J. Hupka, op. cit., s. 266.

116 Niejednokrotnie jego działania znajdowały uznanie w oczach jego przeciwników politycznych. Jaworski podziwiał taktykę arcybiskupa, który będąc w maju 1916 r. w Wiedniu, rozgłaszał tam informację, że Królestwo Polskie opowiada się za Niemcami, licząc, że skłoni to Austrię do konkretnych działań na rzecz sprawy polskiej. W.L. Jaworski, op. cit., s. 99.

117 BLUN, rkps 1492 III, B. Krzysztofowicz, Zapiski wojenne. Notatki pisane w czasie wojny 1914-1918, k. 60.

118 A. Wątor, Narodowa Demokracja w Galicji do 1918 roku, Szczecin 2002, s. 332-333.

119 Podpisał on wcześniej głośną deklarację z 10 XI 1914 r. w sprawie Legionów, w której występowano przeciwko angażowaniu się Polaków z Galicji w sprawy Królestwa i podkreślano konieczność porozumienia się z przedstawicielami pozostałych dzielnic zaborczych. Ibidem, s. 323.

120 J. Hupka, op. cit., s. 204, 208. Szerzej na temat zaangażowania abp. Teodorowicza w prace antybloku (endecja, podolacy, grupa „Rzeczypospolita”) i niedopuszczenie do reformy wyborczej w 1913 r. zob. R. Król-Mazur, Działalność polityczna..., s. 56-65.

${ }^{121}$ W. Sikorski do W.L. Jaworskiego, Legionowo 7 III 1916, w: Listy Wtadystawa Sikorskiego do Wtadystawa L. Jaworskiego i Prezydium Naczelnego Komitetu Narodowego 1914-1918, oprac. Z. Koziński, Z. Pietrzyk, Kraków 1987, s. 148.

${ }^{122}$ APO, Teodorowicz, t. 117, sygn. 428/217[6], Pisma polityczne dotyczace NKN, k. 79. 
za „nielojalne” wobec Austrii zachowanie się i popieranie nurtu niepodległościowego ${ }^{123}$. Po ponownym przejęciu Lwowa przez Austriaków podejrzliwość i niełaska dosięgła także abp. Teodorowicza, któremu zarzucano, że szerzył i popierał polskość Galicji Wschodniej, natomiast nigdy nie zabierał głosu $\mathrm{w}$ interesie monarchii, a w czasie wojny okazywał zupełną obojętność wobec zamierzeń wojennych Austrii. Austriacy nie mogli wybaczyć Teodorowiczowi wypowiedzi dotyczących Legionów i prowadzonej wobec nich obłudnej polityki. Pojawił się pomysł internowania arcybiskupa i osadzenia go w jakimś klasztorze daleko poza Galicja. Dzięki zabiegom posła i profesora lwowskiego uniwersytetu Alfreda Halbana udało się temu przeszkodzić ${ }^{124}$.

We wrześniu 1915 r. biskupi galicyjscy stanęli na gruncie programu unii personalnej Galicji i Królestwa Polskiego z Austrią ${ }^{125}$. Arcybiskup Teodorowicz wraz z bp. Sapieha sondowali w AOK, jakie jest nastawienie władz austriackich do tego projektu ${ }^{126}$. Do programu usiłowali zjednać episkopat Królestwa ${ }^{127}$. Czynili obaj w Wiedniu różne zabiegi, aby uzyskać od Franciszka Józefa obietnicę przyłączenia Królestwa Polskiego do Austriii ${ }^{128}$. Teodorowicz był przez pewien czas propagatorem unii personalnej Austrii z Polska ${ }^{129}$. W październiku 1915 r. biskupi uzyskali zapewnienie cesarza austriackiego, że cesarz niemiecki zdecydował się odstapić Królestwo Polskie Austrii ${ }^{130}$. Kontakty z wpływowymi czynnikami politycznymi w Wiedniu ułatwiały abp. Teodorowiczowi poruszanie się po różnych strefach okupacyjnych. To jego wpływom oraz abp. Bilczewskiego w Wiedniu lwowianie zawdzięczali odwołanie znienawidzonego gen. Letofsky'ego, którego rządy przyczyniły się do masowych aresztowań i oskarżeń o nielojalne zachowanie się wobec Austrii $\mathrm{w}$ czasie rosyjskiej okupacji miasta ${ }^{131}$.

Teodorowiczowi, „opromienionemu blaskiem powagi z czasów inwazji” rosyjskiej, łatwo było uzyskać wielkie wpływy polityczne we Lwowie. Według

${ }^{123}$ R. Król-Mazur, Działalność polityczna..., s. 77.

${ }^{124}$ Ibidem.

${ }^{125}$ We wrześniu 1915 r. abp Bilczewski uzyskał od Franciszka Józefa informację, że połączenie Królestwa i Galicji w całość i przyłączenie do Austrii jest już postanowione. Dziennik Juliusza Zdanowskiego, t. I: 22 VI 1915 - 29 IV 1917, wstęp i oprac. J. Faryś, T. Sikorski, H. Walczak, A. Wątor, Szczecin 2013, s. 130. Jednak w liście W.L. Jaworskiego do Z.A. Tarnowskiego, datowanym na 27 IX 1916 (!), podana jest informacja, że uzyskał w zaufaniu wiadomość od bp. Pelczara, iż wczoraj episkopat Galicji uchwalił na zjeździe w Krakowie poprzeć program związku Królestwa i Galicji w unii personalnej z Austria. ANK, ADzT, sygn. 1127, W.L. Jaworski do Z.A. Tarnowskiego, Kraków 27 IX 1916, s. 511.

${ }^{126}$ W.L. Jaworski, op. cit., s. 129.

127 ANK, ADzT, sygn. 1127, W.L. Jaworski do Z.A. Tarnowskiego, Kraków 27 IX 1916, s. 511.

128 A. Kakowski, Z niewoli do niepodlegtości. Pamiętniki, red. i oprac. T. Krawczak, R. Świętek, Kraków 2000, s. 255, 260.

${ }^{129}$ L. Biliński, Wspomnienia i dokumenty, t. II: 1915-1922, Warszawa 1925, s. 110.

${ }^{130}$ Ibidem, s. 86-87.

131 ANK, NKN, sygn. 507, MF 100, 718, Sprawozdanie lwowskie 14 II 1916, s. 134. 
doniesień delegacji lwowskiej NKN z 14 II 1916 r. działał bardzo czynnie na rzecz podolaków, a w działalności politycznej inspirował abp. Bilczewskiego i politycznie „ustawiał” tamtejszy kler ${ }^{132}$.

Austriacko-niemieckie porozumienie, zawarte w Wiedniu podczas pertraktacji z 11 i 12 VIII 1916 r., w wyniku którego miało powstać samodzielne Królestwo Polskie z dziedziczną monarchią i ustrojem opartym na konstytucji, a którego granice powinny być ustalone po zakończeniu wojny, wykluczyło możliwość przeprowadzenia rozwiąania austro-polskiego, którego orędownikiem byli działacze galicyjscy $\mathrm{NKN}^{133}$. W praktyce oznaczało to, iż dalsze istnienie Komitetu straci sens. Podczas obrad Komisji Politycznej Koła Polskiego zdecydowano o przyjęciu rozwiązania pragmatycznego - nie zmieniać programu, ale i nie pomagać Austrii w jej nieszczerej grze z Niemcami. Decyzji tej nie zaakceptowali socjaliści. Konsekwencją rozbratu konserwatystów z socjalistami było to, że bliżej idei austro-polskiej i NKN znaleźli się galicyjscy hierarchowie kościelni. Arcybiskupa Teodorowicza oraz bp. Sapiehę we wrześniu 1916 r. AOK zapewniało, że nie wszystko stracone ${ }^{134}$.

Akt 5 listopada stanowił zaprzeczenie oczekiwań połączenia Królestwa Polskiego z Galicją. Cesarz Franciszek Józef w dekrecie cesarskim z 5 XI 1916 r. do premiera Ernsta von Koerbera w związku ze wspomnianym manifestem ogłosił, że jeśli ma powstać nowe państwo, należy także Galicji „nadać prawo samodzielnego załatwienia swoich praw krajowych, w pełnym zakresie tego, co pozostaje $\mathrm{w}$ harmonii z przynależnością tego kraju do zbiorowości państwowej oraz jego powodzenia, i tym sposobem dać mieszkańcom Galicji rękojmie ich rozwoju narodowego i gospodarczego"135. W związku z tym Koło Polskie zajęło się od połowy grudnia 1916 r. przygotowywaniem projektu konstytucji przekształcającej Galicję w kraj koronny o atrybutach państwa pod jednolitą nazwa „Królestwo Galicji” ${ }^{136}$. Projekt nie uzyskał akceptacji cesarskiej ani parlamentarnej, a następujący w niedługim czasie zwrot niepodległościowy wśród większości polityków zdezaktualizował koncepcję wyodrębnienia Galicji ${ }^{137}$.

Dla abp. Teodorowicza manifest dwóch cesarzy był dowodem bankructwa dotychczasowych metod stosowanych wobec Polaków i czynił fikcją restaurację

132 Jeden z szanowanych księży miał powiedzieć, że „nie mogą chodzić do NKN ze względu na biskupów [Teodorowicza i Bilczewskiego - R.K.M.]”. Ibidem.

${ }^{133}$ Szerzej zob. D. Szymczak, Między Habsburgami a Hohenzollernami. Rywalizacja niemiecko-austro-węierska w okresie I wojny światowej a odbudowa państwa polskiego, Kraków 2009 , s. $113-176$.

${ }^{134}$ Ibidem, s. 200.

${ }^{135}$ Dekret cesarski w sprawie wyodrębnienia Galicji $z$ dn. 5 listopada 1916, „Z Dokumentów Chwili”, 15 XI 1916, nr 4, seria I, s. 23. Ludwik Mroczka podał, że list wystosowany był dzień wcześniej i przytoczył powyższy cytat w zmienionej trochę wersji. Idem, Spór o Galicję Wschodnia 1914-1923, Kraków 1998, s. 49.

136 Zob. ANK, NKN, sygn. 77, MF 100, 267, s. 280-312.

${ }^{137}$ Projekt ten omówił L. Mroczka, op. cit., s. 50-51. 
Polski. Królestwo Polskie powstałe w wyniku Aktu 5 listopada uznał za parodię państwowości, kraik okupacji, szykan i biedy ${ }^{138}$. Arcybiskup wysunął ideę zjednoczenia wszystkich ziem polskich, lecz jej nie sprecyzował ${ }^{139}$. Podkreślał, że naród polski jest jeden i niepodzielny. Zapowiedź utworzenia państwa polskiego wyłącznie z ziem okupowanych stanowiła dla niego potwierdzenie dokonanych wcześniej podziałów. Tym samym identyfikował się z poglądami wyłożonymi w tzw. Proteście dwudziestu pięciu przeciw Aktowi 5 listopada, który podpisali czołowi działacze ND z Romanem Dmowskim, Janem Jordanem-Rozwadowskim i Erazmem Piltzem na czele ${ }^{140}$.

W odpowiedzi na Akt 5 listopada, na naradzie episkopatu galicyjskiego, która odbyła się w Krakowie 12 XI 1916 r., zaaprobowano projekt konserwatysty Michała Bobrzyńskiego, zakładający, że należy związać pod berłem Habsburgów Królestwo z Galicją. Podkreślono również wolę przyłączenia Wilna i Grodna. Na decyzję biskupów wpływ miał stenogram mowy kanclerza Niemiec Theobalda von Bethmanna-Hollwega, jaką wygłosił na tajnym posiedzeniu sesji budżetowej Sejmu Rzeszy 9 XI 1916 r., a który to stenogram znalazł się w posiadaniu bp. Sapiehy. Kanclerz całkowicie odkrył plany niemieckie i ukazał prawdziwy stosunek kół rządowych do Polaków:

Proklamowanie Polski zapewni nam uległość Polaków, zapewni nam szczerby
w pułkach, pozwoli na wprowadzenie nowych podatków, a wreszcie usprawni nas
w rządzeniu tym krajem. [...] Tereny położone na wschód sa naturalnymi terenami
pod przyszłą kolonizację, co z Bożą pomoca nam się udać musi. [...] Poważna czéść
ludności Polski, zbliżona do nas językiem będzie kadrami pilnie pracujacymi na
rzecz Niemiec. [...] zależne od nas, maleńkie państwo polskie, o ile się utrzyma na
karcie przy pertraktacjach pokojowych, będzie zawsze tak słabe, że mowy być nie
może o jakiejś wybitniejszej roli. Wkrótce przyjdzie czas, że każdy Polak zrozumie, iż
dla niego pozostało tylko jedno - zostać obywatelem niemieckim z ducha i języka ${ }^{141}$.

Politykom NKN trudno było uwierzyć w te słowa. Uważali, że to falsyfikat mowy wygłoszonej na sesji budżetowej, który w Warszawie rozgłaszała ND ${ }^{142}$.

Nie wywołała entuzjazmu decyzja obu cesarzy o utworzeniu Armii Polskiej. Różne środowiska w sposób bardziej i mniej jawny wyrażały swoja dezaprobatę dla tej decyzji ${ }^{143}$. Arcybiskup Teodorowicz bardzo uważnie śledził

138 T.M. Trajdos, op. cit., s. 86.

139 A. Kudłaszyk, op. cit., s. 39.

140 Zob. ANK, ANKN, sygn. 507, MF 100, 718, s. 84.

${ }^{141}$ Cyt. za: M.M. Drozdowski, op. cit., s. 48-49; T. Krawczak, Wkład kościoła $w$ dzieło Niepodległości, w: Warszawa w pierwszych latach Niepodległości, red. M.M. Drozdowski, H. Szwankowska, Warszawa 1998, s. 74.

${ }^{142}$ W Warszawie rozszerzany był przez ND następujący falsyfikat: ANK, NKN, sygn. 105, MF 100, 295, W sprawie polskiej [mowa - R.K.M.] wygłoszona na Komisji budżetowej 9 XI 1916 r., s. 332-334.

${ }^{143}$ W niedzielę 26 XI 1916 r. na ulicach Warszawy porozlepiano plakaty, w których bardzo ostro skrytykowano akceptację przez NKN tej decyzji, pisząc m.in.: „Nie ma prawa oficer 
kolejne posunięcia w tej sprawie. Rozterki, czy będzie polskie wojsko, czy nie, skomentował stwierdzeniem: „jakże to odbiegło od dawnej zuchwałości”144. Obawiał się jednak kolejnych akcji propagandowych, w wyniku których „znowu doktryneria zapanuje nad zmysłem i odczuciem sytuacji i chwili”145.

$\mathrm{Z}$ wypowiadanymi niejednokrotnie przez abp. Teodorowicza słowami pod adresem oszukiwanych przez polityków żołnierzy pokrywały się ich odczucia po decyzji o rozwiązaniu Legionów i utworzeniu Polskiego Korpusu Posiłkowego. W napisanej 29 VIII 1917 r. przez żołnierzy odezwie Do naszych rodaków padły gorzkie, aczkolwiek prawdziwe słowa:

Ale jakeśmy się strasznie zawiedli [...] Wojska Polskiego nie pozwoliliście nam tworzyć, znajdując coraz to inne względy, jedni bali się go jak upiora, inni chcieli pięknej chimery, ale podkopywali i obalali rzeczywistość, śmiesznie ją lekceważąc. Tzw. pasywiści i tzw. piłsudczycy, to byli wrogowie naszych marzeń i pragnień. Piersi chcieli mieć wojsko malowane, drudzy czynili nad nim eksperymenty agitacyjne od początku ${ }^{146}$.

Arcybiskup Teodorowicz bardzo surowo ocenił sytuację, w jakiej znalazł się polski żołnierz po kryzysie przysięgowym. Decydujących o tym pytał:

Za co jednak zamknięto polskiego Legionistę w obozie karnym, gdy on uczynił użytek z prawnie zastrzeżonej dlań swobody? Złożenie przysięgi bowiem przedstawiano Legioniście jako akt swobodnej decyzji. Mówi się wprawdzie wiele o radykalnych prądach wśród młodzieży, ale dlaczegóż - z żalem to podnieść należy - dając jej w ręce takie wartości, jak sumienie ludzkie i miłość Ojczyzny, czyni się to przez wypaczoną formułę przysięgi? Dlaczego wreszcie, pytam dalej, - także i ci Legioniści, którzy wyszli z innego punktu widzenia, którzy formuły przysięgi krytyce nie poddawali, którzy po prostu zaufali Radzie Stanu i niewątpliwie działali w dobrej intencji, - dlaczego i za co, - pytam - ci także zostali ukarani? Dlaczego posłano ich na front $\mathrm{i}$ odjęto im nawet zewnętrznie charakter polskiego wojska? ${ }^{147}$

Teodorowicz uważał, że należy nadal być w opozycji do NKN - przygotowywał nawet „materiał” przeciwko Jaworskiemu. Zwracał uwagę, że w obecnej sytuacji ważne jest utrzymanie wpływów w „Głosie Narodu”148. Jednak, jak pisał w liście do bp. Sapiehy, nawet felietony osób, które na linii politycznej z nim współpracowały, kazał najpierw oddać sobie do sprawdzenia, zanim zostaną opublikowane ${ }^{149}$.

austriacki, pan pułkownik Sikorski legionistów polskich w imieniu narodu, do rozporzadzenia władz niemieckich oddawać!”. Plakat z d. 26 XI 1916, „Z Dokumentów Chwili”, 28 XI 1916, nr 6, seria III, s. 32-33.

${ }^{144}$ AKMK, TS, sygn. V/213, Abp J.T. Teodorowicz do A.S. Sapiehy, [b.m.] 1917.

145 Ibidem.

${ }^{146}$ BUANL, Ossol., op. 1, rkps 6910, Broszura Do naszych rodaków, s. 215.

${ }^{147}$ Interview z JE.X. Arcybiskupem Józefem Teodorowiczem..., s. 187.

148 „Głos Narodu” - organ katolicki wydawany w latach 1893-1939 pod auspicjami Kurii Metropolitalnej w Krakowie.

149 AKMK, TS, sygn. V/213, Abp J.T. Teodorowicz do A.S. Sapiehy, [b.m.] 1917. 
Biskupi galicyjscy na czele $\mathrm{z}$ abp. Teodorowiczem i abp. Bilczewskim z uznaniem przyjęli ogłoszony w różnych gazetach w kraju list napisany 25 IV 1917 r. przez Stanisława Głąbińskiego do prezesa Koła Polskiego Leona Bilińskiego, w którym zdecydowanie żądał zaprzestania dalszych prac nad wyodrębnieniem Galicji w chwili, kiedy przywódcy wielkich państw uznaja i głosza potrzebę zjednoczenia ziem polskich ${ }^{150}$. Głąininski poddał w nim ostrej krytyce politykę Koła Polskiego i NKN oraz orientację austro-polską ${ }^{151}$. Według opinii Bobrzyńskiego i innych konserwatystów list Głąbińskiego „został uknuty z arcybiskupem Teodorowiczem”152. Być może zajęcie przez Teodorowicza tego stanowiska było przyczyna wezwania go przed oblicze cesarza Karola ${ }^{153}$. Sam Głąiński przyznał po latach, że abp Teodorowicz udzielił mu wtedy moralnego poparcia ${ }^{154}$.

Rozgrywające się wydarzenia pozwoliły abp. Teodorowiczowi na zajęcie bardziej otwartego, zdecydowanego stanowiska. Na wniosek Włodzimierza Tetmajera $^{155}$ (z 16 maja) w tzw. uchwałach majowych z 1917 r. Koło Polskie przyjęło, że dążeniem narodu polskiego jest odzyskanie zjednoczonej, niepodległej Polski z dostępem do morza, przy życzliwej pomocy cesarza austriackiego ${ }^{156}$. Kiedy 28 V 1917 r. Koło Sejmowe przegłosowywało rezolucję Tetmajera, na sali rady miejskiej obok posłów sejmowych, parlamentarnych i delegacji Rady Stanów i polityków zaproszonych z Królestwa Polskiego zasiadał abp Teodorowicz wraz z bp. Sapiehą ${ }^{157}$. Jednak przed samym głosowaniem obydwaj hierarchowie wyszli ${ }^{158}$. Odpowiedzią na decyzję Koła Sejmowego było zebranie 31 maja członków Izby Panów z zamiarem skłonienia ich do wydania odezwy dezawuującej uchwały z 28 maja ${ }^{159}$. Na tym zebraniu abp Teodorowicz wystapił z niezmiernie ostra mową skierowaną przeciwko NKN oraz czołowym konserwatystom krakowskim - Bobrzyńskiemu i Jaworskiemu ${ }^{160}$.

${ }^{150}$ Chodziło o wystapienie Woodrowa Wilsona i deklarację Rządu Tymczasowego w Rosji. Głąinínski wystosował kilka listów do prezesa: 15 i 25 IV oraz 8 V 1917 r. R. Król-Mazur, Działalność polityczna..., s. 84. List Głąbińskiego z 25 V 1917 r., zob. ANK, NKN, sygn. 77, MF 100, 267, s. 338-348.

${ }^{151}$ R. Król-Mazur, Działalność polityczna..., s. 84.

${ }^{152}$ W.L. Jaworski, op. cit., s. 186; A. Wątor, Narodowa Demokracja..., s. 338.

${ }^{153}$ APO, Teodorowicz, t. 141, sygn. 35/231[7], Kancelaria Gabinetu cesarza Karola I Habsburga do J.T. Teodorowicza, Wiedeń 24 IV 1917.

${ }_{154}$ Mowa S. Głąbińskiego po śmierci abp. Teodorowicza, „Słowo Narodowe” R. II, 6 XII 1938, nr 347.

${ }^{155}$ Stanowisko, jakie zaproponował Tetmajer, było wypracowane w lwowskiej grupie Ligi Narodowej. A. Wator, Chrześcijańsko-narodowi..., s. 113.

${ }^{156}$ Powstanie II Rzeczypospolitej. Wybór dokumentów 1866-1925, red. H. Janowska, T. Jędruszczak, Warszawa 1984, dok. 152, s. 340.

157 S. Głąbiński, op. cit., s. 272.

${ }^{158}$ W.L. Jaworski, op. cit., s. 194.

159 Bowiem jak zauważył Jaworski, wniosek Tetmajera oznaczał przejście Polaków do ententy. Ibidem.

${ }^{160}$ Ibidem, s. 195-196. 
Uchwała Koła Sejmowego z 28 maja przyspieszyła w zaborze austriackim konsolidację zwolenników orientacji prokoalicyjnej, stwarzając dogodne warunki do zorganizowania nowego ugrupowania politycznego. Przygotowania do jego utworzenia trwały od jesieni 1916 r., a nad projektem pracował internowany Stanisław Stroński. Początkowo proponował wyłonienie na podstawie porozumienia stronnictw Komisji Wykonawczej, która reprezentowałaby opinię polską $\mathrm{w}$ zaborze austriackim. $\mathrm{Z}$ duchownych mieli do niej wejść abp Teodorowicz i abp Bilczewski ${ }^{161}$. Ostatecznie z inicjatywy lwowskiej grupy Ligi Narodowej powstało Zjednoczenie Narodowe, które swój program przedstawiło 10 VII 1917 r. Miało stanowić organizację skupiającą działaczy politycznych i społecznych wywodzących się z różnych opcji, a także przedstawicieli świata nauki i kultury. Jego celem było współdziałanie w „odbudowie zjednoczonej niepodległej Ojczyzny na zasadach demokratycznych”162. Teodorowicz stał się mentorem Zjednoczenia Narodowego (wszedł też do jego kierownictwa), z którym związani byli: Edward Dubanowicz, Stanisław Kasznica, Stanisław Stroński, Tadeusz Cieński. Organizacja utrzymywała łączność ze swym odpowiednikiem w Królestwie Polskim ${ }^{163}$. Teodorowicz w pierwszych dniach lipcach 1917 r. uważał, że w obecnej chwili nie jest nam potrzebna żadna organizacja polityczna. Należy utworzyć organizację apolityczną albo jak to nazwał „złączenie silniejsze kilku osób z nazwiskami i układanie sprawy polskiej”164.

Arcybiskup Józef Teodorowicz dał wyraz swoim myślom i uczuciom na temat rozgrywajacych się wydarzeń $\mathrm{w}$ dwóch słynnych mowach wypowiedzianych w austriackiej Izbie Panów. Pierwsza miała miejsce 30 VI 1917 r., a więc niecały miesiąc po uchwaleniu przez Sejm Krajowy rezolucji Tetmajera, stwierdzającej, że jedynym dążeniem narodu polskiego jest odzyskanie niepodległej zjednoczonej Polski z dostępem do morza.

Ta wypowiedź zbiegła się z kryzysem przysięgowym w Królestwie Polskim. Arcybiskup skorzystał z okazji debaty w Izbie Panów nad prowizorium budżetowym i wygłosił mowę odpowiadającą duchowi uchwały Koła Sejmowego z 28 V 1917 r. Opinia Teodorowicza, która była też stanowiskiem endecji, została wyrażona bardzo dosadnie. Mówił w imieniu narodu, a nie Galicji, domagał się „pełnej restytucji” Polski, atakował koncepcję Mitteleuropy i jej wiedeńskich zwolenników z pozycji suwerenności polskiej polityki narodowej, jej niezależności od kalkulacji państw centralnych, natomiast w organicznym związku z idea niepodległego państwa polskiego. Odmówił aktom rozbiorowym legalności w świetle prawa międzynarodowego i zasadności na płaszczyźnie racji politycznych, tym samym kwestionując prawo Austrii do Galicji. Występował bardzo ostro przeciwko polityce niemieckiego sojusznika. Ostrzegał też Wiedeń: „Wojna

${ }^{161}$ A. Wator, Narodowa Demokracja..., s. 346. W swojej drugiej pracy stosował jednak nazwę Komitet Wykonawczy. Zob. idem, Chrześcijańsko-narodowi..., s. 122.

162 J. Malinowski, op. cit., s. 49-50.

${ }^{163}$ Ibidem; R. Król-Mazur, Działalność polityczna..., s. 85-86.

164 AKMK, TS, sygn. V/217, Abp J.T. Teodorowicz do bp. A.S. Sapiehy (?), Lwów 3 VII 1917. 
jeszcze nie jest rozstrzygnięta, wciąż czekamy na rozmowy pokojowe i pokój. Nie jest obojętne dla monarchii, jak się będą rozwijać stosunki z Królestwem Polskim w przyszłości"165. Zwracał też uwagę na siłę agitacji rewolucyjnej z Rosji. Podczas przemówienia, które z nikim nie zostało uzgodnione, przedstawiciele rządzącego establishmentu Galicji cichaczem opuszczali salę obrad ${ }^{166}$.

Wincenty Witos wspominał, że wystapienie abp. Teodorowicza miało wiele elementów bardzo mocnych i cechowała je niezwykła odwaga. Polscy członkowie Izby Panów początkowo solidaryzowali się z mówca, a swoją dezaprobatę okazali dopiero, kiedy rząd objawił swoje niezadowolenie. Zmuszono nawet Teodorowicza do złagodzenia części przemówienia ${ }^{167}$.

Druga mowa (30 X 1917) miała miejsce niedługo po rozwiązaniu się NKN w Krakowie. Ponieważ politycy galicyjscy wiedzieli o niej, wymogli na arcybiskupie złożenie wstępnej deklaracji, że „przemawia tylko w swoim imieniu”168. Arcybiskup w miażdżący sposób demaskował po raz drugi obłudną taktykę państw centralnych wobec Polski. W pierwszej części wystapienia mówił o fałszywej polityce zaborców. Wskazując na zachowanie się Niemiec w czasie polskich walk niepodległościowych 1794, 1831 i 1863 r., odbierał im prawo zarzucania narodowi polskiemu niewdzięczności i niewywiązania się z obietnic złożonych w czasie wojny (zapewnienie wywołania powstania na tyłach Rosji, niechęć do utworzenia Armii Polskiej w Królestwie Polskim). Następnie arcybiskup mówił o niemieckich projektach aneksji i podziału Polski, ogałacaniu kraju z surowców, urządzeń, żywności, wywozie tysięcy Polaków na przymusowe roboty do Niemiec, poniżaniu warszawskiej Rady Stanu. W szczególnie płomiennych słowach ujął się za krzywdą legionistów - piętnując bezsensowna przysięgę proponowaną wojsku polskiemu, rozbicie legionistów i ich więzienie. Na zakończenie powołując się na opublikowaną 1 VIII 1917 r. przez Ojca Świętego notę pokojową ${ }^{169}$, oświadczył, że jedynym, opartym na sprawiedliwości, realnym dążeniem wszystkich Polaków jest przywrócenie państwowości ${ }^{170}$.

${ }^{165}$ Cyt. za: A. Wator, Narodowa Demokracja..., s. 343-344.

166 R. Król-Mazur, Działalność polityczna..., s. 86.

167 W. Witos, Moje wspomnienia, Paryż 1964, s. 142-143.

168 R. Król-Mazur, Działalność polityczna..., s. 87.

169 Benedykt XV zapewniał w niej o neutralności Stolicy Apostolskiej w trwającej nadal wojnie. Postulował restytucję terenów zabranych - wspominał o Armenii, państwach bałkańskich i Polsce. Jednym z warunków pokoju miała być odbudowa Polski, ale tylko w granicach byłego Królestwa Polskiego - to ograniczenie do terenów Królestwa Polskiego wywołało niezadowolenie w społeczeństwie polskim. Z. Zieliński, Papiestwo i papieże dwóch ostatnich wieków, cz. 2: 1903-1978, Poznań 1986, s. 55-56, 76; ks. J. Wołczański, Adam Stefan Sapieha w korespondencji z biskupami Galicji (Małopolski) w latach 1900-1939, w: Kardynat Adam Stefan Sapieha. Środowisko rodzinne, życie i dzieło, red. S. Stępień, Przemyśl 1995, s. 123.

170 J. Teodorowicz, $Z$ dziejowej chwili, Lwów 1918, s. 9-67; Bojownicy i kapłani za sprawe Kościoła i Ojczyzny w latach 1861-1915, cz. 3, t. IV, oprac. P. Kubicki, Sandomierz 1940, s. 273; A. Wątor, Narodowa Demokracja..., s. 358. 
Arcybiskup uznał swoje wystapienie w takiej formie za konieczność, bowiem „szczera i otwarta mowa często $\mathrm{w}$ tych czasach użycza pomocy dyplomacji, która posługiwać się może, tylko tonem szeptu"171. Jego wystapienie w Radzie Stanu, jak również zaangażowanie w działalność Książęco-Biskupiego Komitetu Pomocy dla Dotkniętych Klęską Wojny (delegacja lwowska), znalazło uznanie w oczach społeczeństwa nie tylko we Lwowie ${ }^{172}$.

I wojnę światową abp Teodorowicz wspominał po latach w następujący sposób:

Przypominam sobie żywo te ciężkie chwile, te czasy pogrążające naród w grubych ciemnościach, które rozciagnęły się nad nami i jakby się sprzysięgły, aby wszelką nadzieję ludzką w przyszłość narodu zdławić. Bo jakże tu było wyjść z błędnego koła, skoro widziało się, że przeciwko sobie stoją w dwu walczących ze sobą obozach ci, co naród więzili. Z nich, po ludzku mówiąc, jeden musiał zwyciężyć, a którykolwiek by był zwycięzca, dla Polski - wedle praw ludzkich - zawsze powstać musiała przegrana. I dlatego nie dziwię się, że były różne kombinacje, ażeby dla Polski, choć częściowo się coś z tej wojny okroiło i bodaj coś przypadło jej z łaski zwycięzców ${ }^{173}$.

Reasumując, należy podkreślić, że abp Teodorowicz odegrał znaczącą rolę w wydarzeniach politycznych rozgrywających się podczas Wielkiej Wojny. Analizując jego poglądy, widzimy, że zarówno w sensie ideowym, jak i politycznym nie oddalił się od ND. Potwierdza to zgodność w tak zasadniczych kwestiach, jak orientacja międzynarodowa (Niemcy największym wrogiem), postulat utrzymania Galicji Wschodniej w polskich rękach czy konieczność pozyskania ruchu ludowego. Jak słusznie zauważył Jan Engelgard, abp Teodorowicz, który wzią na siebie politykę neutralizowania działań obozu proaustriackiego i piłsudczykowskiego, miał na tym polu większe sukcesy niż endecja ${ }^{174}$. Jego rola wzrosła jeszcze bardziej po 1915 r., kiedy wielu czołowych działaczy narodowodemokratycznych musiało wyjechać do Rosji, aby uniknąć prześladowania ze strony państw centralnych. Teodorowicz, który pozostał na miejscu i miał wielkie wpływy w różnych kręgach, postrzegany był przez opozycjonistów jako najgroźniejszy przeciwnik. Inteligencja, wytrwałość, zdolności oratorskie, rozeznanie polityczne, liczne kontakty w różnych środowiskach w kraju i za granica, czujność i odwaga to cechy abp. Teodorowicza, dzięki którym stawał się pożądany w różnych środowiskach i nieustannie zabiegano o jego przychylność. Sam pozostawał do końca wierny swoim przekonaniom, a jego działaniom zawsze przyświecał cel - dla dobra Polski, katolickiej Polski - tak jak ją widział i rozumiał.

171 J. Teodorowicz, $Z$ dziejowej chwili..., s. 12.

172 Towarzystwo Szkoły Ludowej w Stanisławowie wyłożyło do podpisu adres do abp. Teodorowicza wraz z odpowiednią odezwa. „Głos Narodu” R. XXV, 31 XII 1917, nr 299, s. 2.

${ }^{173}$ Cyt. za: R. Król-Mazur, Dziatalność polityczna..., s. 91.

174 J. Engelgard, Religia i polityka - Józef Teodorowicz $i$ Narodowa Demokracja $w$ latach 1902-1918, w: Teodorowicz. Mówca i patriota..., s. 126. 


\section{Streszczenie}

$\mathrm{W}$ prezentowanym tekście zostały przedstawione poglądy polityczne jednego z czołowych działaczy politycznych początku XX w., związanego z ugrupowaniami politycznymi wyrosłymi z Narodowej Demokracji, jak i konserwatystami wschodniogalicyjskimi - ostatniego arcybiskupa ormiańskokatolickiego Józefa Teofila Teodorowicza. Artykuł zawiera analizę jego stosunku do rozwijającego się na ziemiach polskich ruchu irredentystycznego, a następnie jego wybór opcji politycznej w momencie wybuchu Wielkiej Wojny i stosunek do Naczelnego Komitetu Narodowego - organizacji politycznej utworzonej w Krakowie w sierpniu 1914 r. w celu konsolidacji galicyjskich środowisk niepodległościowych i sprawowania opieki politycznej i finansowej nad organizującymi się Legionami Polskimi. Przedstawia opinie i poglądy abp. Teodorowicza dotyczące najważniejszych wydarzeń rozgrywających się na ziemiach polskich do końca 1917 r.

\section{It was wrong not to respect the heart psychology of a young warrior..." Archbishop Józef Teofil Teodorowicz's criticism of the SNC and the Legions}

The article presents political opinions of one of the leading politicians of the early twentieth century, associated with both political groups which developed from the National Democracy, and the conservatives of Eastern Galicia - the last Armenian Catholic archbishop Józef Teofil Teodorowicz. The article contains an analysis of his attitude towards the irredentist movement developing in the Polish lands, and then his choice of a political option at the outbreak of the Great War and of his attitude towards the Supreme National Council (SNC) - a political organisation established in Krakow in August of 1914 to consolidate Galician independence communities and to protect, politically and financially, the Polish Legions which were being organised at that time. It also presents Archbishop Teodorowicz's views on the most important events occurring in the Polish lands up to the end of 1917.

\section{Bibliografia}

Bojownicy i kapłani za sprawe Kościoła i Ojczyzny w latach 1861-1915, cz. 3, t. IV, oprac. P. Kubicki, Sandomierz 1940.

Drozdowski M.M., Dylematy polityki Naczelnego Komitetu Narodowego wobec Niemiec (do aktu 5 listopda 1916), „Studia Historyczne” R. LV, 2012, z. 1 (217), s. 27-49.

Engelgard J., Religia i polityka - Józef Teodorowicz i Narodowa Demokracja w latach 19021918, w: Teodorowicz. Mówca i patriota, red. T. Skoczek, Warszawa 2015, s. 115-141.

Faryś J., Wątor A., Edward Dubanowicz 1881-1943. Biografia polityczna, Szczecin 1994.

Krawczak T., Wkład kościoła $w$ dzieło Niepodległości, w: Warszawa w pierwszych latach Niepodlegtości, red. M.M. Drozdowski, H. Szwankowska, Warszawa 1998, s. 64-81.

Król-Mazur R., Działalność polityczna arcybiskupa Józefa Teofila Teodorowicza $w$ latach 1888-1923, Kraków 2013.

Król-Mazur R., Idea odrodzonego państwa polskiego w pogladach galicyjskich ugrupowań politycznych do utworzenia Naczelnego Komitetu Narodowego, „Politeja” 2010, nr 2, s. 269-300.

Kudłaszyk A., Elementy doktryny społeczno-politycznej abp. Józefa Teodorowicza, „Roczniki Teologiczno-Kanoniczne" 1980, t. XXVII, s. 23-42.

Molenda J., Pitsudczycy a narodowi demokraci 1908-1918, Warszawa 1980.

Mroczka L., Spór o Galicję Wschodniq 1914-1923, Kraków 1998. 
Pająk J.Z., Lwów podczas pierwszych dni Wielkiej Wojny 1914-1918, w: Znani i nieznani międzywojennego Lwowa. Studia i materiaty, t. III, red. M. i M. Przeniosło, Kielce 2012, s. $109-125$.

Snopko J., Społeczeństwo Królestwa wobec Legionów Polskich po akcie 5 listopada, w: Lata Wielkiej Wojny. Dojrzewanie do niepodlegtości 1914-1918, red. D. Grinberg, J. Snopko, G. Zackiewicz, Białystok 2007, s. 279-293.

Stopka K., Ormianie w Galicji Austriackiej, w: Ormiański pasterz Lwowa ksiadz arcybiskup Józef Teodorowicz na tle dziejów ormiańskich, red. W. Osadczy, ks. M. Kalinowski, M. Jacov, Lublin-Lwów 2015, s. 73-112.

Suleja W., Orientacja austro-polska w latach I wojny światowej (do aktu 5 listopada 1916 roku), Wrocław 1992.

Szymczak D., Między Habsburgami a Hohenzollernami. Rywalizacja niemiecko-austro-wegierska w okresie I wojny światowej a odbudowa państwa polskiego, Kraków 2009.

Szymczak D., Niemiecko-austro-węgierski spór o przyszłość Polski a narodziny państwowości polskiej w 1918 roku, w: Rok 1918 w Europie Środkowo-Wschodniej, red. D. Grinberg, J. Snopko, G. Zackiewicz, Białystok 2010.

Teodorowicz J., Dwie epoki. Mowa wypowiedziana w r. 1913 w archikatedrze lwowskiej w 50-ta rocznice powstania 63 r., w: idem, Kazania o Bogu i Ojczyźnie, Warszawa 1999.

Trajdos T.M., Uwagi o działalności politycznej i przekonaniach arcybiskupa Józefa Teodorowicza, w: Teodorowicz. Mówca i patriota, red. T. Skoczek, Warszawa 2015, s. 68-95.

Wątor A., Chrześcijańsko-narodowi. Z dziejów nurtu politycznego do 1928 roku, Szczecin 1999.

Wątor A., Galicyjska Rada Narodowa w latach 1907-1914. Z dziejów instytucji obywatelskiej, Szczecin 2000.

Wątor A., Narodowa Demokracja w Galicji do 1918 roku, Szczecin 2002.

Zieliński Z., Papiestwo i papieże dwóch ostatnich wieków, cz. 2: 1903-1978, Poznań 1986.

Zięba A.A., Czy można być ormiańskim patriota i polskim biskupem jednocześnie? Arcybiskup Józef Teodorowicz jako Ormianin, w: Ormiański pasterz Lwowa ksiadz arcybiskup Józef Teodorowicz na tle dziejów ormiańskich, red. W. Osadczy, ks. M. Kalinowski, M. Jacov, Lublin-Lwów 2015, s. 199-232.

Biog r a m: Renata Król-Mazur - dr, Instytut Nauk Politycznych i Stosunków Międzynarodowych UJ. Główne zainteresowania: historia nowożytna i najnowsza Polski i powszechna (szczególnie dzieje Rosji, Ukrainy, Kaukazu); mniejszości narodowe i etniczne (ze szczególnym uwzględnieniem Ormian). Publikacje: Miasto trzech nacji. Studia z dziejów Kamieńca Podolskiego w XVIII wieku (Kraków 2008); Działalność polityczna arcybiskupa Józefa Teofila Teodorowicza w latach 1888-1923 (Kraków 2013); Na wschód od linii Curzona. Księga jubileuszowa dedykowana profesorowi Mieczysławowi Smoleniowi (współredakcja; Kraków 2014) oraz kilkadziesiąt artykułów opublikowanych w języku polskim, ukraińskim i angielskim. E-mail: reniakrol@poczta.onet.pl. 